\title{
Assessing the Productivity of the UK Retail Sector
}

\author{
JONATHAN REYNOLDS*, ELIZABETH HOWARD*, DMITRY DRAGUN*, \\ BRIDGET ROSEWELL $^{* *} \&$ PAUL ORMEROD ${ }^{* *}$ \\ ${ }^{*}$ Templeton College, University of Oxford; ** Volterra Consulting Ltd.
}

\begin{abstract}
Several recent comparative studies have shown a labour productivity gap in respect of UK retailing when compared with other countries, notably France and the US. This article seeks to identify, through an overview of existing data and related research, the extent to which retail productivity in the UK compares to global competitors and attempts to reach a consensus on the factors that determine retail productivity, whilst highlighting common performance measures for retailers and Government to use in measuring future productivity trends. Methods employed include a review of published studies; interviews with industry participants in the UK and a small number of leading retailers in the USA; and an analysis of a specially created database of the performance of over 200 US, UK and French retail companies. We find that it is unwise to draw definitive conclusions from aggregate international economic analyses of the sector; that a wide variety of efficiency indicators are employed by the sector in practice; and that there are significant differences in the structure, operating and regulatory environment for retailing in the UK which impose costs on retailers that are not necessarily incurred in other countries.
\end{abstract}

KEY WORDS: Productivity, retailing, international, labour, efficiency, regulation

\section{INTRODUCTION}

This article reports on a study of the comparative productivity of the UK retailing sector in relation to retailing in other markets ${ }^{1}$. Discussion of "retail productivity" in general terms conceals the real tension that exists between economic approaches to the measurement of productivity within the retail sector - themselves potentially problematic whether at macro or at the firm level - and the metrics commonly used by retail practitioners to demonstrate the efficiency and effectiveness of their firms to internal and external stakeholders. Our study therefore sought to deal with a complex and ambiguous problem: the definition, measurement and analysis of "retail productivity" in ways that are relevant and meaningful to the various interested parties involved.

The original research combined a critical assessment of existing 'top-down' studies of productivity, with an assessment of the utility of key productivity and performance indicators employed by retailers. It was undertaken through a mixture of interviews with industry participants in the UK, including the leading retailers and retail analysts, a small number of

\footnotetext{
1 The study from which this article is drawn ('The Templeton Report') was commissioned by the UK Department of Trade \& Industry as part of the deliberations of the Retail Strategy Group. The RSG was established in 2003 to allow "the retail industry and UK government to work in partnership to identify key issues that have an impact upon the competitiveness and productivity of the retail sector, and together to take action to maximise the opportunities for, and minimise the threats to, UK retailers." The RSG report makes a number of recommendations to be taken forward by Government, retailers and other stakeholders and which will result in closer working partnerships. (See www.dti.gov.uk/sectors retail.html.) The work of the RSG was supported by three studies looking at retail productivity, land assembly for retail development and how the financing of retail developments influence the leasing and retail regime. We are grateful to the Department of Trade \& Industry for waiving copyright over the material appearing in this article.
} 
interviews with leading retail CEOs and CFOs in the US, alongside analysis of a specially created database of the performance of over 200 US, UK and French retail companies between 19992003. The database represented a wide spectrum of multiple retailing in each country for which corporate data were available.

The tension between different approaches to productivity is not peculiar to retailing. A recent Work Foundation study made it clear that "the productivity debate in the UK bas fragmented into disciplinary and lobbying silos" (Work Foundation, 2003). It observed the narrowness of the technical debate on productivity and noted that "any study that is going to make a contribution that addresses .. wider economic issues has to take a broader approach to productivity". We agree. Retailing contributes to UK economy, society and environment in many ways, not all of which are measurable in productivity terms, and indeed it may be necessary to see the various contributions as involving a series of trade-offs.

Retailing, however, also provides additional hurdles to straightforward international comparison. Retail distribution belongs to a sector of the economy often considered 'hard' or 'impossible to measure' by economists using broad output-to-input ratio techniques. Availability of appropriate data on retailing at all, or of consistent and comparable kinds, is problematic. One of the consequences of these hurdles is a relative lack of attention paid to retailing, and to services more generally by economic analysts and policymakers, because other sectors provide for relatively greater certainty in measurement.

The concept of output lies at the heart of any productivity analysis. Unlike, say, manufacturing where the service element is normally very small, retail "output" includes a service element that varies from very large to very small, with considerable scope for trade-offs. This is an important consideration in international comparisons of retailing, since there are consequences for measurement and different trade-offs in different countries.

We need to get beyond a simple measure of service. We must distinguish:

- Outputs which are broadly concerned with the levels and quality of service provided by labour inputs. (Crudely, we can interpret this as meaning more help on the shop floor.) These are likely to be captured by economic analyses of labour productivity, provided that such studies do adequately and comparably measure the quality of labour employed, rather than just its quantity,

- Outputs which are about more than the goods provided, and not just 'service', but are summed up in the retail 'proposition' or offer which consumers choose to pay for. (We can interpret this as the retail format.) These outputs are unlikely to be captured by conventional productivity analyses and the mix of propositions is likely to differ country by country, and

- Contributions to society and the environment, such as maintenance of the existing urban fabric. (These can be seen as unmeasured externalities to the retail system.) As externalities, these factors are also outside the scope of conventional productivity analyses.

It may be that the resulting scope for internalising/externalising a retailer's costs and benefits works to limit the value of labour productivity as a single indicator of the sector's overall contribution to the UK economy. 
Consumers make store choices in the context of the overall competitive structure of retailing, and primarily from the set of retailers available in any particular location. A key part of retail output is therefore provision of goods and services in a particular place.

Comparative work in hindered by the retail industry's lack of definitions. There is no single definition of retail format - the term is used both in a generic sense and also to describe the specific offer of a particular retailer. It has been suggested that retailing as a sector lacks a single common basis for classification (Brown, 1986). For example, Retail Intelligence gives the following definition of department stores:

"Stores selling a wide range of goods including significant proportions of clothing and household goods, usually on several floors within one building, with sales area over 2,000 sq. $m$ and at least 25 sales employees.” (Retail Intelligence, 2000)

This definition could be supplemented by a number of other descriptions listed on the website of the International Association of Department Stores. An equally wide array of definitions exists for other retail formats such as discounters, superstores, variety stores, and power centres. WalMart has been variously described as a discount department store operator, hypermarket, and power centre. While all these descriptions are likely to bear some semblance to reality, an allembracing, clear-cut definition of each retail format remains elusive. Many contemporary retailers, Wal-Mart included, comprise elements acquired during the drive for value-adding opportunities outside their traditional domains. In addition, the boundaries between the traditional formats are becoming blurred, for example, Carrefour's MAGALI format combines the features of the open market and boutique-type environment, all within the traditional - but modified - hypermarket setting.

A major reason for the definition difficulties is the multi-dimensional nature of retail formats. As Figure 1 shows, retail format can be viewed on a number of dimensions, among which size and price are the most often used. The figure demonstrates the challenge of classifying retailers according to the dimensions defined - in order to be meaningful any classification should be based on a multitude of interacting and overlapping characteristics. Supermarket operators, for example, are often perceived as the easiest to classify since they have been one of the most familiar retail formats around and appear to lend themselves readily to analysis. This, however, may not be an easy task, as the example of Tesco shows. This company operates five distinct retail formats in the UK (Extra, Superstore, Metro, Express and tesco.com), of which Superstore is the company's contemporary core format. The other concepts are relatively new and exhibit different range and service characteristics. Abroad, Tesco's Lotus 'hypermarkets' in Thailand and Homeplus 'department discount' stores in South Korea can hardly be fitted into any of the existing retail formats. How would one then define Tesco? At this stage, the only suitable classification might be a rather unconvincing 'multi-format grocery operator'. In terms of productivity, expecting Tesco's Metro format to meet the same productivity targets as, say, its superstore format (let alone the South Korean store format) would be unrealistic: we are comparing apples and pears.

Retail format is best viewed as a multi-dimensional phenomenon particular to each company. From the point of view of productivity, every format will exhibit a distinctive mix of trade-offs of efficiency against effectiveness in relation to the kinds of dimensions in Figure 1, which may or may not conform to the optimum efficiency.

Format is important in assessing productivity because of the relationship with business model. The discount formats which are so significant in the USA, mean not simply that retailers aim to 
sell lower priced goods: rather it is that the business model is different. There are wide variations of course, but in general this model relies on minimizing complexity, costs and services in nofrills stores, limiting ranges, and maximising stock turn. Labour inputs are minimised; store property costs are likely to be low. Alternative models rely, for example, on driving sales through range and choice of product with added services, in different, probably more expensive, locations and stores. Labour inputs, and other costs, are likely to be higher. Gross margin is likely to be higher and stock turn lower.

\title{
Designing a retail proposition
}

Retailers must choose from the list of store choice criteria seen by consumers as important, to determine how they wish to compete. We can distinguish between order-winning criteria and orderqualifying criteria (Hill, 2000). Qualifiers are those criteria that a company must meet for a consumer to even consider it as a possible choice. However providing or attaining these criteria does not win orders. Winners comprise the criterion, or criteria, against which consumers will make the final choice. Strength in both winning and qualifying criteria build switching barriers and generate loyal customers.

Figure 2 provides insights into UK grocery shopping behaviour and distinguishes between the most important factor in store selection and those factors which are important but not critical. In this context, for example, more shoppers find the 'one stop shop' criterion a winning one than price alone, although price is a significant qualifier and, for a smaller group of consumers, a key winning criterion in its own right. Convenience is the only other criterion to attract a greater than $10 \%$ appeal as a main factor in store choice. This example suggests that there may be three key positioning dimensions in the market available to UK grocery retailers: a 'full service' range onestop shop; a low price offer; and a convenience offer. Each is relevant to certain customer segments at certain times; each offers different benefits and services for customers for the same basket of goods. Of course, this matches very closely what we know about how this sector is presently structured.

\begin{abstract}
'It's a different shopping model, isn't it? The nature of retail food competition in this country [UK] reminds me a little bit of what happens in evolution in the natural sphere, in a sense that you look at these curious beasts and wonder why they evolved in that way. The answer is that you don't have the abstract model of saying that the customers want the lowest price - instead what the customers want is a combination of price and services... We are choosing where we think our customers want the balancebetween price and value - to be struck." (UK retailer interview)
\end{abstract}

One of the key trade-offs in developing compelling strategic positioning is therefore that between price and a bundle of non-price factors, of which level of service may be one factor. For example, in the case of the consumer's selection of a clothing retailer, customer surveys have shown that non-price consumer choice differentiators include: a wide range of sizes, good stock availability, clothes that are 'a bit different', a wide range of colour ways and sizes, good changing areas and more helpful staff. Whilst there has been a growing market in the UK for discounted clothing, these non-price factors still remain important for many consumers.

Determining the correct trade-off is a dynamic game between competitors where only long-term growth in market share and profitability can provide evidence for the success of any positioning strategy. The kinds of choices that have to be made are similar for a retailer in any market; but the trade-off between efficiency and customer appeal will be different between countries, and within countries - between and within categories. These will be important considerations in explaining any gap in aggregate retail productivity between countries. Our interviews with 
industry participants in the UK, including the leading retailers and retail analysts, confirmed this perception:

"[Our] business is customer focussed, it is not a production line, this means that the balance between service and efficiency has to be achieved depending on the desired country service levels. These service levels differ across countries depending on their cultural differences and bistory. In South Korea, our stores have a much higher number of people in selling positions across the shop floor, which reflects the shopping patterns there. We could not replicate the far lower number of people in countries such as Thailand, Poland or the UK. This can have a big impact on performance and is another reason why cross-country comparisons have not been carried out on a regular basis." (UK retailer interview)

The consequences for the measurement of efficiency and performance were expressed by one of the UK's leading fashion retailers:

'Isn't efficiency (and productivity) all wrapped up in your brand positioning and therefore not really something for anyone to comment on? If French Connection wants to sell higher-priced things and spends lots of money on advertising - that's one brand positioning. If we are a value retailer - that's another brand positioning. Then perhaps it makes sense to disaggregate very simply by looking at higher-priced brands separately from value-priced brands? That might help to see whether selling more things at lower prices generates more efficiency than selling fewer things at higher prices." (UK clothing retailer interview)

As a consequence, it is not at all clear that all retailers share in the 'productivity gap' that national aggregate studies of the UK economy have found. And even if the sector as a whole or in part does neither is it at present altogether clear whether this is for statistical, structural or business environmental reasons.

\section{THE AGGREGATE APPROACH TO MEASURING RETAIL PRODUCTIVITY}

\section{What do existing studies say about retail productivity?}

There is considerable policy interest in the productivity of the UK economy, both at the overall level and the level of individual sectors. Analysis of labour productivity in retailing has been undertaken as part of this more general interest, with results for retailing often decomposed from an aggregate level. Typically, productivity is measured in terms of labour productivity: that is to say the output generated for every unit of labour input. Usually output is defined as gross value added and labour input as either per worker or per worker hour. Increasingly this interest has focused on comparisons of the levels of productivity in the same sectors in different G7 countries. There is also interest in how the level of productivity changes over time within the UK and across countries.

Several recent studies have made cross country comparisons of retail sector productivity. All have concluded, to a greater or lesser extent, that overall average labour productivity in the UK retail trades, when expressed in a common currency, is lower than in other major G7 countries, notably than that in France and the US. The same studies, although differing in degree, agree that whilst the labour productivity gap between retailing in the UK and US narrowed in the early part of the 1990s, it widened significantly in the latter part of the decade. Three major studies are of particular relevance: 
- that by the McKinsey Global Institute (1998) which carried out a special decomposition of both labour and total factor productivity in the food retail sector;

- that by the National Institute for Economic and Social Research (O’Mahoney \& de Boer, 2002) which focused on labour productivity, and

- a more recent study by the Groningen Growth \& Development Centre and the Conference Board (van Ark et al., 2002) which focused upon labour productivity and the particular role of information and communications technology (ICT) in influencing differential productivity growth.

There have also been a number of more recent, more focused analyses of US/UK retail productivity. In general terms, our initial observation is that all these studies work with relatively standard methodologies, are broadly careful and meticulous in their technical approach, as befits their origins, but are hampered by the fragility of the international data environment which leads to the need to make some often heroic assumptions. Further, these studies are first and foremost aggregate comparisons of productivity between national economies. Commentary on retailing often comprises a small component of the overall analysis. The decomposition of such 'topdown' analysis to the sectoral level, and particularly for a sector with which so many conceptual difficulties are associated is challenging to say the least. Any problems arising at an aggregate level may produce still more surprising results at a more detailed service industry level. For example, the estimates produced by one study suggest that labour productivity in hotels and catering is $82 \%$ higher in France than in the UK, and around 40\% higher than in the US (O'Mahoney \& de Boer, 2002:37). This is seriously hard to believe.

The estimates in the table below are not directly comparable because the authors use different definitions, time periods and means of converting estimates of labour productivity in national currencies into a single one. We should say at the outset that none of the differences of approach necessarily challenge the finding of there being a productivity gap between retailing in the UK and France and US, but they cast doubt on its scale and character.

The gap between retail productivity levels in the UK and US shown by the NIESR study in 1996 appears to be larger than that for the McKinsey work for the previous year, but the McKinsey data deal with food retailing only, whereas NIESR encompasses retail and repairing. By 1999, the gap shown by NIESR has increased still further and is larger than that demonstrated by McKinsey between the UK and France. Although Table 1 appears somewhat sparsely populated, the NIESR calculations are based upon an extensive sectoral productivity database (NIESEC02), which contains a wide range of data series underlying the productivity calculations. We did not have a similar level of access to the detailed working underlying the McKinsey analysis.

McKinsey employ total gross margin as their output measure, defined as sales less cost of goods sold. NIESR employ an output measure of value added per hour. We discuss the general technical difficulties affecting output measures, to which the measurement of retail output may be particularly susceptible and broader problems of definitions of retail output, below.

But labour productivity estimates are also susceptible to the way in which inputs are calculated. Such calculations depend fundamentally on the assumption either that jobs are equivalent 'inputs', or on estimations of hours worked. The sources above used hours worked, imputed from average employee data. Hours worked data are generally the most vexed element of international labour productivity calculations and the general difficulties are amplified for retailing. There are two particular relevant factors: 
- the composition of employment in retailing, and

- the timing of data collection in relation to the operational dynamics of the sector.

For example, McKinsey's labour input of total hours worked for food retailing, including selfemployment could, they suggest, have been affected by a margin for error as a result of the many small independent food retailers in the UK. Retailing in the UK also has a very high self-reported rate of part-time working (39\%) compared with other European countries (Figure 3) ${ }^{2}$. The equivalent figure for the US in 2001 was 27\% (Bureau of Labor Statistics, 2003). Part time jobs have increased very rapidly; contracts of very varied types with just a few hours work per week have proliferated over the last decade. This feature is stronger in the UK than any of our comparator countries. Although numbers of part-time jobs are measured, we have found no robust data about the number of hours worked in these jobs.

McKinsey estimated that the propensity to employ a higher number of lower value added workers in UK retailing (temporary or very part-time casual staff) might account for some 15 percentage points of the difference between French and UK labour productivity levels. We examine some of the structural reasons that might explain this later, but if the measurement of this component of labour input is inadequate and/or different between countries, then there may be statistical concerns also.

Secondly, the timing of data capture on average employees by sector is particularly problematic for retailing. European Labour Force Survey data tend only to cover the Spring of each year (March-May). The UK Labour Force survey during the period in question gathered data at different points in the year. One recent smaller study using micro data took retailers' average employee numbers in the peak business month of December as an input to a comparison of manufacturing-service sector productivity (Barnes, 2002). This is hardly representative of average employment in the sector and will, of course, artificially depress labour productivity levels. Any errors made or international inconsistencies in adjustments for these kinds of timing factors are likely to be magnified in sectors like retailing, where there is strong seasonality.

One final example demonstrates the sensitivity of analyses of this kind to small changes in method. The use of Purchasing Power Parity (PPP) estimates from the OECD is a conventional approach to developing robust international comparisons of productivity. The NIESR study updates its previous work by using 1996 estimates instead of the 1993 ones used in an earlier piece of work. These estimates are taken as read. However, the measure of output depends crucially on these comparisons.

The UK recently introduced a new method of using deflators - providing an annual update of weights, rather than a quinquennial one. This has had the effect of increasing the growth rate over long periods of time. Statistics have thus suddenly closed at least part of the productivity gap. Even though the effect may be small, it should remind us of the importance of recognising that these are all statistics, subject to error and methodological impacts. The McKinsey study was sufficiently concerned that the use of the OECD food PPPs would not fully reflect country differences in service levels that the researchers undertook a cross-check using a basket of goods purchased at similar stores in the US, UK and France. This was used to construct a bespoke PPP, which produced similar results to the OECD method.

\footnotetext{
2 According to Eurostat, the definition of part-time working in the European Labour Force Survey is based upon "a spontaneous response by the declarant. It is impossible to make a more precise distinction between full-time and part-time employment, since working hours differ from one Member State to the next and from one branch of activity to the next."
} 
Table 2 summarises the results of the main studies in respect of retail labour productivity growth. Both main studies tracking growth agree that it is only in the 1995-2000 period that we saw US rates of retail labour productivity growth outstripping those in the UK, which in turn outstripped those in France. The Conference Board study also makes the point that not only did the major increase in US labour productivity appear to have taken place in the 1995-2000 period but that US growth during 1990-95 appeared to be below that in the UK. And whilst the Conference Board study also demonstrates a US-EU gap, it decomposed European country contributions towards this to demonstrate that the UK was amongst the vanguard within Europe in growing labour productivity during 1995-2000 (Figure 4).

How do these studies account for this differential growth? The main NIESR report makes no comment on this (the figures are taken by us from the accompanying tables). Nor does the Conference Board study attempt a detailed explanation of the UK's position in relation to Europe or the US. But the latter study is focussed generally upon the slower pace of ICT diffusion amongst ICT-using industries within Europe, and it would be reasonable to assume that the timing of such diffusion might have been somewhat different in the UK compared to much of the rest of Europe in the early 1990s, but that this was overwhelmed by faster ICT diffusion in the US in the latter part of the 1990s. A later report by McKinsey, however, is quite specific:

\section{A quarter of that increased productivity [in the US] came from retailing -- and about one-sixth of the improvement in retail productivity came from general merchandise, most of it directly or indirectly from Wal-Mart. (reported in National Centre for Policy Analysis, 2002)}

Nobody would claim that retail output is solely dependant on the input made by the sector's workers. Differences in labour productivity can be in part explained by differences in the use of other inputs, investment in physical capital for example. Given the particular importance of shop location for the profitability of retail operations, the economic cost of occupying land should also feature in any productivity comparison. For instance, the economic cost of occupying land in the UK is considerably higher than in the US or France (40\% more expensive per square metre of selling space than the US and 15\% more than France, according to McKinsey; we return to this point later). Because land and floorspace are more expensive, UK retailers need to make much more productive use of land and capital than in the US and France, since acquiring extra space will not necessarily be cost-effective. None of the studies made allowances for the particular exposure of UK retailing to higher land costs in calculating benchmark levels of labour productivity in the sector, but the McKinsey study estimated that smaller grocery store sizes (a logical outcome of differential land costs) contributed some five percentage points of difference in labour productivity between the US and the UK.

Different retail formats, methods of trading, and the institutional framework within which the sector operates all mean the likelihood that traders in different countries will use different combinations of land, labour and capital is high. Labour productivity will vary on average because of these compositional effects. For example, whilst the benchmark level of retail labour productivity for food retailing calculated by McKinsey did not include compositional effects, the study estimated that format differences accounted for some five percentage points of the gap between the US and the UK as well as between the UK and France (Figure 5). Any meaningful comparison of productivity needs to take these kinds of marked differences into account before passing judgement on relative country performance. In their absence any comparisons must be subject to severe qualification.

A broader approach to making productivity comparisons attempts to define and measure differences in the various inputs which contribute to output either at the individual firm level or 
in an aggregate of firms. The economic value of a sector's output is defined explicitly, as is (ideally) the economic cost of buying the inputs which generate that output. At one extreme, output - if properly measured - might be explained entirely in terms of the capital, labour and land inputs used to add value to the purchase of materials. Again the cost of resource inputs should ideally be properly measured to reflect their true economic cost. If the value of the sector output exceeds the economic costs of the sector's inputs, then the explanation of output must also rest on something else as well as resource inputs. This something else is caught by the catch all phrase of total factor productivity (TFP)

This is an attractive alternative for measuring the efficiency of a sector for which we know the international variability of factor costs is high. Indeed, in conceptual terms TFP is a superior measure of productivity to labour productivity alone. However, it is also a technically and statistically more challenging alternative to measuring productivity than focusing on labour alone, and for this reason it is not surprising that few studies have sought to take this approach. The study by the McKinsey Global Institute was one exception and one which examined both labour and total factor productivity within food retailing. Whilst it was critical of the levels of the UK's labour productivity during the early 1990s, it praised performance in TFP terms.

"Our study suggests that UK [food] retailers are not distinguished by their labour productivity: they acbieve only $75 \%$ of the benchmark set by France. But in terms of total factor productivity - labour and capital productivity combined - the United Kingdom sets the global standard jointly with France." (McKinsey Global Institute, 1998)

McKinsey's analysis used total gross margin per square metre of selling space as the proxy for capital inputs in their study and this metric provides $40 \%$ of the TFP calculation.

A study by Basu et al looked at TFP growth and gave some findings for retailing (see Table 3). Major sectors contributing to the growth in TFP in the US included the wholesale trade, retail trade, finance and insurance.

Their results are rather puzzling, as others have pointed out:

".. the absolute numbers for UK TFP growth in ... retail for the second half of the 1990s are puz:ling. Can it be that TFP growth was actually negative in the UK during that period? [Using OECD data] for wholesale and retail trade together gives a growth rate of real value added of $3.2 \%$ a year, a growth rate for employment of $1.0 \%$, so a rate of labor productivity growth of $2.2 \%$... This suggests an unusually high rate of capital accumulation during the period, capital which was not used very productively.” (Blanchard, 2003)

Basu et al argue that lower TFP may be a result of investments in ICT leading to the diversion of resources to reorganisation and learning. They also noted that US ICT prices fall faster than UK ones, so that the UK's ICT and capital investment costs will grow more rapidly for otherwise similar kinds of investments, with a correspondingly differential effect upon productivity. Given that retailing is an intensive ICT-using service, we might expect the differential to be considerably higher for the sector.

One of the major features of US economic growth in the last few years has been an extraordinary growth in labour productivity, following an earlier period of relatively slower growth. This most recent spurt has apparently been unaccompanied by any capital deepening. Explaining the resolution of this apparent paradox is one of the key components in explaining any apparent gap 
in productivity growth between the US and Europe. There appear to be several possible explanations:

- inconsistencies that result from different national approaches to the measurement of ICT investments (Triplett, 1999; Pilat, 2002)

- the relative 'invisibility' of such investment (Brynjolfsson et al, 2002)

- the time taken for the benefits of ICT investment to emerge (Economist, 2003).

One broad consequence of this may have been to have under-estimated US productivity gains in ICT-using services in the 1990-95 period and to have over-estimated it during 1995-2000; and correspondingly to have under-estimated ICT-using services growth in Europe, particularly the UK.

The most worthwhile estimates of both TFP and labour productivity are those that are able to overcome problems of definition and measurement of both outputs and inputs. However, these are particularly challenging in the context of cross-country comparisons of the retail trades. We conclude overall that these problems are such that any results obtained must be treated with considerable caution.

\section{Understanding the limitations of the top down approach}

We now turn to a more wide-ranging critique. We agree with others who have written extensively on this topic:

"Despite major efforts by national statistical offices and international organisations, data problems still limit the possibility of comparing growth performances across countries and sectors, as well as over time. Comparability problems have always affected international analyses of growth performances but are particularly relevant at present because of the different pace and comprehensiveness with which different countries have adopted new measurement techniques in their national accounts. In addition, the growing emphasis on growth in quality instead of growth in quantity and the large share of hard to measure services in total output are some of the factors adding to these measurement problems" (Scarpetta et al, 2000).

"We cannot be sure how much of the differences we observe are the result of inadequate measurement of services output and differences across countries in measurement methodology" (van Ark, 2002).

Essentially, the total factor productivity levels in countries relative to the UK are calculated (see for example O’Mahoney \& de Boer, 2002) as follows:

$$
\ln \mathrm{TFP}_{\mathrm{i}, \mathrm{uk}}=\ln \mathrm{Q}_{\mathrm{i}, \mathrm{uk}}-\alpha \ln \mathrm{L}_{\mathrm{i}, \mathrm{uk}}-(1-\alpha) \ln \mathrm{K}_{\mathrm{i}, \mathrm{uk}}
$$

where the symbol $\ln$ denotes natural $\operatorname{logs}$, Q is total value added in country i relative to the UK (real output), $\mathrm{L}$ is relative labour input in the two countries, $\mathrm{K}$ is relative capital stocks in the two countries, and $\alpha$ is the share of labour in value added averaged across the two countries.

The same approach is used in comparing the same industry, such as retailing, in two countries. In this case, the Q, L and K refer to the aggregate industry levels of output, labour and capital, rather than to the national aggregates. 
The difficulties with the approach arise in a number of ways. Equation (1) may appear scientific, but it conceals many assumptions, each of which may or may not be a reasonable approximation to reality. The key ones are as follows.

\section{The problems of measuring aggregate retail output}

We focus on this particular issue because it is of great relevance to the retail sector. The measurement of output in (1) requires adjusting current price estimates by the rate of inflation to obtain estimates of real output. There is strong evidence that the rate of inflation is substantially over-estimated in official data, and the growth in real output is substantially under-estimated. Imagine, for example, a single store whose range of goods, prices, level of capital input and value added are absolutely identical in every respect in two particular periods of time which are being compared. The quality of the labour force is also identical. The only difference is that in one period, the level of staffing on the tills is, say, only half that of the other. Using equation (1), it is obvious that when the store employs more labour, it has lower total factor productivity. Yet there is clearly a difference in the offer which the store makes in the two periods. In one, customers are more likely to have to waste their time queuing at the till.

Of course, if customers value speedy till service sufficiently, once the store uses more labour it may attract more custom and raise its overall level of value added. But if its competitors respond by increasing their staffing levels at the till, this comparative advantage may disappear. The industry as a whole sells a better quality 'output' (i.e. product + service) to the consumer, but its TFP has fallen.

This example is by no means a purely imaginary construct. Something very similar to this occurred when the UK food superstore retailers introduced Sunday trading. There was an increase in convenience for the customers. But the amount of labour used increased, and the effect on total sales was very difficult to discern, so TFP - had it been calculated using (1) would have fallen. In Australia, measured retail productivity declined when shopping hours were extended - the extra convenience was not taken into account in the statistics (Quiggin, 2003).

We can think of the above example as a particular case of the more general concept of a change in quality of an existing product.

Many of the difficulties with the usual economic analyses arise from the problem of measuring inflation. This is needed in order to convert nominal values on, say, output, into real values. Theoretically, the price level should be measured using a cost-of-living index (COLI) (Boskin et al., 1996; Abraham et al., 1998; Triplett, 2001; Hausmann, 2003).

The standard way of measuring inflation takes a particular basket of goods chosen to be representative of consumer spending at some point in time. The cost of purchasing this same basket of goods in a different period is then calculated. The substitution problem arises because the use of a fixed basket of goods does not take into account the fact that consumers will shift away from goods that have become relatively expensive to those which have become relatively cheaper. (And of course is further complicated by the international variability in basket composition.)

A fairly substantial literature exists on this question, but it is probably the least important of the problems which arise in the measurement of inflation. Calculations of the potential size of this bias suggest that official estimates over-state the rise in the COLI by about 0.3 per cent a year in the US (Shapiro \& Wilcock, 1997) and around 0.1 per cent in the UK (Blow \& Crawford, 2001). 
More importantly, retailers have lump sum costs of staying in operation which they must distribute over consumers. Consumers have fixed costs associated with visiting any given retailer. So the retailer must offer a basket of goods which justifies the trip by the consumer. Given the heterogeneous nature of consumers, the natural outcome is intertemporal and interstore price dispersion. This is formalised in economic theory with the concept of Ramsey pricing (Bliss, 1988). Prices no longer reflect marginal cost. Instead, product differentiation is used to allocate portions of fixed and other costs in ways which takes account of the price elasticities of demand. The impact of this is estimated to be substantial. For example, in the United States the official estimate of the Consumer Price Index has been calculated to over-state the rate of inflation in food retailing by 1.4 percentage points in each year from 1978 to 1996 (Nakamura, 1999). In turn, this implies considerable under-estimates of real output in the sector.

Many new products increase consumer welfare substantially. A number of studies have been carried out in the United States which show that new products such as the minivan or even Apple Cinnamon Cheerios provide large welfare benefits to consumers (cited in Hausmann, 2003). There is typically a long time lag before new products enter into the calculation of the price level in official statistics, and even then no adjustment is made for the consumer gains which they provide relative to previously existing goods.

The increase in consumer welfare can be measured in the same way as with the introduction of new products or, in the case of retailing, new shops or new shop formats offering new ranges or services. Again, official methods of calculating the price level do not make sufficient allowance for the gain in consumer welfare. This is another source of over-estimation of inflation:

"Present methods probably still fail to capture many important quality improvements occurring in these [service] industries" (Gullickson \& Harper, 2002).

Outlet bias is particularly important in retailing, where some countries have seen dramatic shifts in consumer purchasing habits over the past ten or twenty years. We have not been able to find a reference which quantifies the gain to consumer welfare of shifts in retail outlets, but in principle it seems that these could be substantial. In the United States, for example, the official data gradually rotate products sold in the calculation of the Consumer Price Index. However, when a given product sold at a department store is rotated out of the index and the same product sold at, say, Wal-Mart is introduced in its place, the official procedure treats these as different goods and not as a reduction in the price of the same good.

\section{Alternatives to the aggregate approach: measuring retail productivity at the micro-level}

Recently economists and statisticians have taken to using firm-level data in an attempt to understand aspects of the retail productivity 'problem' that appear in top-down approaches. However, the quality and quality of information available to measure firm or establishment productivity in the retail sector is much poorer than in manufacturing (Doms, Jarmin \& Klimek, 2001). Firm level data allow the calculation of productivity and its decomposition by size of business and by sector. No internationally comparable data are available, but preliminary UK information provides food for thought. Figure 6 shows Gross Value Added productivity by size of business for all retailing (SIC 52). The data indicate that, in general terms, the largest retailers are more productive than the smaller.

Another interesting area capable of analysis using firm-level data collected by an establishment industry census or relational database such as the UK's Interdepartmental Business Register 
(IDBR) is that involving the entry and exit of firms. Some commentators argue changes in the dynamics of firm entry and exit are part of a wider explanation of TFP. Sector productivity can increase because of the way sector resources are able to move to their most productive use. Conversely, the scope for TFP improvement is likely to be constrained by factors which impede investment location, competition, firm or store expansion, add to the costs of firm entry and exit, or which allow waste to persist and the relatively inefficient to survive. Entry and exit analysis both at country and at local level is therefore also potentially of considerable policy interest, since any barriers to entry (such as regulatory constraints) may work against improving productivity if new entrants are more productive, and drive out less productive firms (Doms, Jarmin \& Klimek, 2001).

At the store level (rather than at the level of the firm), early studies in the US seemed to show that virtually all of the productivity growth in US retail trade during the 1990s was accounted for by more productive entering establishments over much less productive exiting establishments (Foster, Haltiwanger \& Krizan, 2002). By comparison, a later study using UK micro-level data between 1997 and 2001 calculated that the entry and exit of firms was a lesser fraction of productivity growth in retailing than in the US (Haskel \& Khawaja, 2003; Griffith et al., 2003).

\section{Conclusions on the aggregate approach}

We must make clear that most practitioners themselves recognise that this is a very broad brush approach. Whilst a standard defence, particularly in cross-country comparisons, is to argue that at least the same approach is being applied consistently, it would be extraordinary if each of the problems associated with the TFP approach exhibited the same degree of relative importance in each country.

This is particularly the case in the very important practical question of the measurement of retail output. The theoretical issues discussed above, combined with the revolution in retailing, discussed subsequently, are really quite fundamental. Before the TFP approach can reasonably be applied, a very detailed knowledge is required of how each of the relevant national statistics bodies deal, or fails to deal, with each of the issues raised. This same point applies to an indicator of productivity which is much easier to calculate, namely output per worker or per worker hour. It is precisely the measurement of the level of output which is problematic. And, of course, this very simple measure fails to take into account the potential contribution to output of capital, which is exactly what the TFP approach is designed to do.

These difficulties pose a question which neither we nor anybody else thus far have been able to answer. This is whether the qualification which needs to be given to any estimates of retail sector productivity measured by either labour productivity or TFP, applies equally across countries. It cannot be said whether current estimates of labour productivity are more or less equally unreliable nor the degree of their unreliability. They do therefore need to be treated with considerable care. Do the estimates of retail trade productivity across countries require so much qualification in their interpretation that the numbers are meaningless? This has to be a judgement assessed against the broad magnitude of the differences. As a measure of relative economic efficiency, comparisons of TFP are preferred over comparisons of labour productivity alone. The striking feature about the estimates of labour productivity and TFP is the difference in the UK ranking they portray. On the preferred measure of TFP, the UK emerges according to McKinsey as productive as its major G7 comparator. If the productivity of two countries, or two industries in different countries, were very different, the crude, broad brush approaches of output per worker or TFP would almost certainly reveal a substantial gap. But what is at issue is not whether retailing in, say, France has double the retail labour productivity level of the UK. Rather, 
it is claimed that the gap may be of the order of 20 per cent. The problems associated with the aggregate approach are such that it is difficult to argue that such a conclusion is reliable and indeed could even be within a putative margin for error. It would be most unwise to attempt to draw firm policy implications from the analysis.

\section{THE RETAILER'S APPROACH TO MEASURING PRODUCTIVITY AND PERFORMANCE}

Retailers are of course mindful of the need to manage the productivity and efficiency of their businesses. However, the larger publicly-quoted retailers tend to avoid aggregate economic approaches to the measurement of productivity, in favour of firm-level financial or operating measures and benchmarks that are meaningful to investors and shareholders - and which are more amenable to comparison and control. Whilst smaller and unquoted retailers have fewer stakeholders to convince, they similarly rely upon a relatively common set of operating and performance ratios.

\section{Retail Key Performance Indicators}

A majority of retailers we interviewed see the top-down economic notions of productivity labour, capital and total factor - as being not particularly useful in practice. This should not surprise us. The major reason is that the aggregated view of productivity as espoused by economic theory does not help retailers gain practical insights into their own efficiency or, ultimately, effectiveness as organisations or as a sector. Most retailers' preference, instead, is to manage the productivity of the various elements of business - labour and space in particular - via cost controls, which then allows for further aggregation of the relevant information into financial performance metrics. Often, balanced scorecards and their equivalents are used to drive the internal understanding of the business and operating improvements.

UK retailers, almost without exception, define productivity as achievement of integrated targets in the following areas:

- Sales

- Product range

- Service levels

- Availability

- Customer satisfaction (price-value-service-convenience components)

- Employee contribution (often measured in terms of labour turnover)

- Operating \& financial performance.

Further financial performance metrics are communicated to the various stakeholder groups and serve as the foundation for assessment of the retailers' success. It is important to realise that the UK retailers are very operationally focussed in their measurement of retail productivity, although admittedly the managerial emphasis and relative importance of specific measures may not be uniform across the individual companies.

"Productivity [in retailing], ultimately, is the balance between the social side - training and so on - and the financial side. These both should go hand in glove. If you train people better, you should get more sales through. The third element is IT - using the efficient systems, in stores in particular, transaction processing and so on" (UK non-food retailer interview) 
This statement suggests productivity is about the skills of the labour force, use of technology and how the two are combined. Economists, we suggest, could happily agree with this.

A multitude of Key Performance Indicators (KPIs) are used by UK retailers, but a set of some 21 commonly-employed indicators recurred in our discussions, although their relative importance varied by category and size of retailer. The level of detail in measurement terms compared to topdown aggregate studies is striking. Those related to efficiency can be broadly summarised in the areas of labour, space and capital. (Space and capital KPIs are separately identified below, since this is how retailers think of them, although we recognise that in economic terms, space KPIs can be considered as a subset of capital measures.)

\section{Labour KPIs}

- Labour cost budgets (weekly/monthly) for each store

- $\quad$ Overall labour costs (including as percentage of sales)

- $\quad$ Sales/profit per employee

- $\quad$ Sales/profit per hour worked

- $\quad$ Gross margin return on labour (GMOL)

- $\quad$ Units sold per hour worked

- $\quad$ Till throughput (Items per hour going through the checkout till)

- Efficiency ratio (the ratio of hours required to run the store efficiently according to the model, to the actual hours used)

- Staff turnover

- Various customer satisfaction measures

Space KPIs

Sales/profit density (sometimes in units per square foot)

Stock availability (closely relates to and determines space productivity)

Ratio of selling vs. non-selling space

Linear density (in an experimental stage for many)

Trading intensity, or balance of customer traffic, and physical limitations of stores

Sometimes, no measures of space efficiency are used. Instead, the emphasis is put on reaching the optimal configuration of the selling space among the categories.

Capital KPIs

$\begin{array}{ll}- & \text { ROCE and its variations } \\ - & \text { Economic profit or EVA } \\ \text { - } & \text { Payback period } \\ \text { - } & \text { DCF-based (Discounted Cash Flow) metrics } \\ \text { - } & \text { Cost of maintaining the capital base (store base) } \\ \text { - } & \text { Depreciation as percentage of sales }\end{array}$

While we do not suggest that these 21 commonly-employed KPIs are suitable for simple application as exhaustive measures of retail productivity, we certainly do believe that they capture important aspects of productivity from the viewpoint of the agents responsible for bottom-up productivity improvements. What most have in common is that both the input and the output 
generated are often measured very indirectly. Whilst it would be helpful to know why change occurs in the costs of occupancy as a percent of gross margin, for example, the lack of availability and inconsistency of such data in corporate accounts precludes such a discussion.

The view of UK retailing from outside, from its US best-in-class peers, supports much of this perception. The choice of KPIs is not dissimilar, especially in the areas of labour and space although the choice of KPIs also reflects some of the different priorities of US retailers towards their investors to that in the UK. Amongst the larger US retailers there is greater emphasis on overall utilization of capital.

"The emphasis in the UK is on gross margins and ratios, not on overall utilisation. .. Our stock market is definitely different from the UK's. Our market primarily looks at growth and utilisation of capital. In my opinion, the UK's market fundamentally looks at operating margins, with much less emphasis on growth. Because of our growth orientation, even with slimmer operating margins, if a US company's growth line is there, the hope is that future operating margins will improve." (US retailer interview)

This is one of the reasons that a number of US businesses find Economic Value Added $\left(\mathrm{EVA}^{3}\right)$ to be an attractive measure of capital effectiveness. Some companies apply EVA to space utilisation, considering the capital cost of rent and fixtures and deducting this from the gross margin contributed by the space to arrive at a true economic profit. This is what we might call 'fractional' EVA, or the EVA attributed to a particular factor of retail production. Essentially, this comprises the gross margin contribution from the space. This is an analytical approach that is not commonly practiced in the UK, and it would be worth further investigation. Some US firms incentivise their management based upon EVA targets.

The importance of EVA in the context of retail productivity relates of course to the fact that EVA reflects the ultimate economic profit of a company. After the providers of capital (both equity and debt) have been paid in full, the remaining economic profit is the reflection of the company's ability to add value beyond the cost of capital. Potentially, EVA per unit of labour or EVA per square foot could be used as a summary measure of productivity, although care would be needed because of variation in hours worked, in part because of double counting on the cost of labour or space and in part because of the possibility of the measure being seen as under rewarding workers or landowners.

Economic profit indicators were felt by many retailers to be good measures for periodic selfcontrol of the business, yet they were less suitable as practical business monitoring tools. The main reason is the practical difficulty associated with the inter-divisional allocation of capital and its cost, together with transfer pricing.

There are a number of general difficulties with EVA. Firstly, it is not, strictly speaking, a measure of output in the same sense as gross margin or net profit margin. Instead, EVA is the net added value, with the imputed, risk-adjusted capital charge explicitly subtracted from the cash flow (NOPAT) generated by the business. Thus, EVA is not particularly compatible with the measures of gross value added aggregated using top-down, macroeconomic methods. Secondly, EVAbased measures do not allow the bottom-up aggregation of corporate data through to the macrolevel. This is impossible because the costs of capital are very different across companies and sectors. Thirdly, varying accounting and corporate reporting procedures across countries make it very problematic to arrive at consistently comparable EVA estimates.

${ }^{3}$ EVA $=$ NOPAT - Capital Employed $x$ Cost of Capital, where NOPAT is Net Operating Profit After Taxes. 
The 21 KPIs listed above are widely used by retailers, though with some significant variances and modifications derived from the particular needs of different businesses. There is a clear distinction between the operating, day-to-day metrics of productivity and strategic, financial reporting measures. For current operations, the retailers we surveyed used total sales growth and like-for-like (LFL) growth as the most important indicators. Progression of gross margin was also important, but many elements (e.g. trade promotions, supplier funding, stop-loss provisions) can only be reliably measured on slightly longer timescales than are operationally convenient. Thus, gross margin is not a tool of operating management although it may be more useful in longerterm monitoring.

We found that there was a wide variation in the usage and importance of particular KPIs by subsector or category. Some retailers, especially fashion-driven companies in the clothing segment, did not attach much consideration to space usage or employee productivity. Instead, the overriding goal was to generate sales enough to justify the significant capex incurred on securing the prime-rate locations that such retailers felt were paramount to their success. In contrast, home improvement retailers in the study were much more focused on space utilisation, employee productivity and profit density.

If we are to argue that retailing is a distinctive industry because of its particular concerns with the intangibles of service quality and format, a very important finding is the lack of definitive measures of effectiveness: for measuring customer satisfaction with the proposition. It might be argued that if a format is ineffective, then customers will vote with their feet, but whilst many UK retailers have their own ways of measuring levels of satisfaction - through surveys, mystery shoppers and the like - there is nowhere near the degree of consensus in this area compared with the range of efficiency measures in use.

Some of the US retailers we spoke to seem to have addressed this question more scientifically:

"In sales, we conduct several evaluations of every associate weekly that measures the effectiveness of their
sales presentation and its adherence to company standards. These evaluations are scored and store
management is held accountable both to financial results and behavioural results." (US retailer)

A third-party organisation founded in 1994 - the American Customer Satisfaction Index (ACSI) tracks US levels of satisfaction by sector and by company and is a uniform and independent measure of the household consumption experience ${ }^{4}$. The score for a particular industry consists of an average of its company scores, weighted by the revenues of the companies included. At the individual firm level, the ACSI provides a consistent measure of customer satisfaction for comparative purposes as well as at segment, sectoral and industry level within the US. There are as yet no international equivalents of the ACSI on which to base comparative work.

The picture that emerges from the analysis of productivity- and efficiency related KPIs used by the UK retailers is richly diverse and portrays overall productivity as intensely specific to the particular circumstances of the sector, product category and the choices made in terms of brand positioning. The retailers approached overwhelmingly reject the notion of 'average productivity': aggregated numbers and averages are irrelevant because the actual comparisons \& benchmarking are made versus best in class - often internationally - rather than against a notional average. We were struck by the extent to which efficiency and the link to performance was at the forefront of thinking of each retailer interviewed. As the Finance Director of a leading grocery retailer put it:

\footnotetext{
${ }^{4}$ http://www.theacsi.org
} 
"Running a retail business, quite frankly, is a pretty remorseless grind. Every year you look, and every year you try to find some productivity savings to try to drive the mandated (inflation-linked) salary increases and combat general cost inflation right across the business." (UK grocery retailer interview)

\section{Evidence from corporate data}

How well do retailers perform on an international comparative basis using their own published efficiency and performance indicators? We chose to examine a sample of US, UK and French retailers, representing a wide spectrum of multiple retailing in each country for which corporate data were available. For the UK, the sample included 92 retailers who represented $64 \%$ of the total retail sales in 2001 (excluding cars, spare parts and foodservice); for the US, the samples consisted of 96 retailers, (37\% of the total US retail turnover in 2001); and for France, 13 retailers, $(72 \%$ of combined retail sales in 2001$)$. For the French retailers, data in a format suitable for comparisons was available for the last two years only. Although we fully recognise the limitations of the database, we nevertheless firmly believe that such analysis should supplement the top-down approaches to measuring retail productivity.

\section{Employee productivity}

The following two figures provide an illustration of the relative efficiency of UK retailers with regards to the utilisation of labour. The analysis is of a poorer quality in this area than in others because of the assumptions required and the caveats that apply here are similar to those in the aggregate economic analyses. An immediate observation from the figures might be that UK retail employees are less productive than their French (significantly) and American (less significantly) counterparts. The efficiency gap is especially noticeable with regards to sales productivity: the average retail employee in France generated sales of nearly $\$ 235,000$ of OECD PPP equivalent, versus $\$ 156,000$ in the US and $\$ 152,000$ in the UK.

A word of caution is immediately in order: the average numbers of employees were normalised in order to provide a consistent basis for comparison. Specifically, retailers in the US do not report full-time equivalent (FTE) numbers; nor do they report the average numbers employed during the year at the end of the financial year - instead, only the actual numbers are reported at the year end. More importantly, employee numbers took no account of the mix of the labour force in relation to full-time versus part-time employees. Not converting to FTE equivalents will depress UK labour productivity in this analysis, but we cannot say to what extent.

With regard to profit-based productivity (measured in terms of net profit), the performance gap is perceptibly less significant. Moreover, it appears that in recent years (2002-2003) this gap has narrowed dramatically. Net profit is certainly preferable to gross margin for international comparisons. For example, in the US, retailers routinely exclude SG\&A (Selling, General and Admin expenses) from Gross Margin, whereas the UK retailers usually include some elements (or all) of SG\&A in the category called "Cost of Sales". US retailers look more profitable than their UK counterparts if gross margin is used as the measure, but the gross margin measures are not comparable. Net profit, on the other hand, is a measure reflecting the 'bottom-line performance' after all business expenses have been made, and is a better reflection of the 'true' profitability of the business for the purposes of comparison, though various elements between the top-line sales and bottom-line net profit my be differently counted by different retailers. If percent gross margin stays the same but percent net margin increases, the cause may be a reduction in costs of trading relative to either purchasers or sales. This is an unambiguous efficiency improvement. If markets are not competitive, increasing net margin could just reflect increased prices and 
monopoly. However, net margin is a closely watched number, simply because this is the source of the dividends for shareholders.

We recognise that the use of net profit margin is perhaps less satisfactory from the viewpoint of the economy as a whole than it is for assessing individual firms. The usually suggested measure of Gross Value Added (GVA) does not correspond well to net profit margin. (From the standpoint of the economy as a whole the issue is how much income is generated by the use of a piece of resource called capital and another called labour. At the very least GVA should equal the marginal product of both capital and labour equivalent to their value in their next best alternative use. At best GVA should reflect a higher return than this. A good proxy for this higher return is net profit.) One of the advantages of using gross profit for measuring productivity is that it is a good first-order approximation of the value added per employee; a good practical shortcut. Provided that the elements of such approximation are agreed in advance and are consistently applied throughout the industry, aggregated gross profit could be linked up to GVA on the macro-level. Indeed, the basis for National Accounts estimates of retail trade gross value added is retailers' returns on gross margin subsequently adjusted.

On the whole, we view data findings from aggregated corporate sources inconclusive in relation to labour productivity. On the one hand, UK retailers appear to lag behind foreign equivalents in terms of sales productivity. On the other hand, the comparative gap may exist simply due to imperfections in data availability, methodology and measurement.

\section{Space productivity}

By contrast, UK retailers perform exceptionally well with regard to sales density and profit density. The common explanation often put forward by casual observers of the UK retail scene is that the higher densities are 'natural' in UK retailing due to inherent geographical limitations UK retailers must inevitably 'cram more people into stores'. This is not the only explanation. Many retailers interviewed emphasised that range is the primary and by far the most important driver of the customer's interest in a retail store's offer. It is widely recognised that the UK retailers are excellent at creating an attractive range, and range per se has little to do with the physical limitations of the stores. Retailers who own their property are in a different position from those who pay rent to third parties: it is possible some may have lower space costs. This saving might affect the amount of space they use, or be used in various other ways, with effects on the density calculations. There has been a trend, however, in the UK for retailer-owners to sell and lease-back their property. We do not have the data to analyse the renting/ owning split in the UK or other countries, and to know whether it makes a difference to the international comparisons.

Not only do UK retailers have higher and increasing sales densities than their international competitors, but they also have higher profit densities. Sales and profits do not necessarily go in step. A retailer may have a higher sales density but a comparatively low profit density, in which case there is reason to doubt its productivity achievements. That UK retailers are best on sales and profits compared to those in our other country samples points to an efficient control of space. 


\section{Financial productivity}

Figures 11 and 12 provide a comparative perspective on financial performance. According to the ROCE ${ }^{5}$-based data, UK retailers fell behind their US counterparts after 1998-99 and French counterparts in 2002-03. One of the possible explanations is that, having invested significant funds in supply chain management, ICT improvements and refurbishment of the store portfolio in the early part of the period, UK retailers are now in the process of catching up with their overseas rivals. Another possible explanation is that much of this capital expenditure is made in more expensive buildings and land than in the US.

The differences in operating profit margin could partly be explained by higher capital intensity, as well, but another significant structural reason, at least in relation to the US-UK comparisons, is the presence of the discounting sub-sector in the US - of a scale and character that simply does not exist to the same degree elsewhere. US discounters are more efficient, more profitable, and provide better returns on their capital employed. Without this group of 'discounters' (11 within the sample of 96 for the US), overall US financial productivity would be significantly lower.

\section{Ranking performance}

As a conclusion to this section on retailers' performance measures, we can present an initial table ranking UK firms against international peers. Differences in accounting standards and retailer category, size, strategy, product mix, international spread and culture make it difficult to identify best practice in terms of corporate efficiency at the individual firm level, but our database of over 200 leading retail firms in the UK, US and France - for which information was available - does allow us to develop a rudimentary ranking table, against employee and space productivity metrics. The construction of performance tables of this kind is usually unrewarding. On the one hand the firms in scope are self-selected. In this case efficiency is equated with size which is probably acceptable as a starting point. On the other hand the cut off is somewhat arbitrary so that a large proportion of the retail trades (particularly systematically smaller UK firms) are excluded from the comparison.

Table 4 identifies for companies with more than $\$ 1$ bn market capitalisation the top twenty performing firms in terms of four key productivity measures. UK firms are separately identified. The table again confirms that in space productivity terms, UK retailers do better than their counterparts in the US. UK firms take seven out of the top ten places in the first two columns. Although they perform comparatively less well on employee-related productivity equivalents (with only three out of the top ten ranked firms) the top two performing firms in labour productivity terms in our analysis are UK businesses. Further, similar UK names feature in the upper echelons in the rankings for all four measures. However, when we examine capital measures in Table 5, it is to find a smaller proportion of UK retail businesses, with the exception of specialist apparel retailing. The ROCE ranking is especially interesting, given what we have already said about the larger US retailers seeking to demonstrate a much greater competence in overall utilization of capital, as a result of the emphasis within the stock market there.

We have not been able to identify any operational best practices which clearly distinguish the best performers from laggards. It is clear that each good performer succeeds with a specific combination of product range, store size and style, location, strategy, as well as operation. There

\footnotetext{
${ }^{5}$ ROCE - Return on Capital Employed (EBIT/TCE, where EBIT is Earnings Before Interest and Taxes, TCE, Total Capital Employed $=$ Total Assets - Current Liabilities)
} 
are variations in the latter of course but it is not these which explain the prime differences, such as they are, between the performance of UK retailers and those in other countries.

\section{Conclusions on the retailer's approach}

Examination of reported corporate data approximating to macro-economic indicators of productivity as well as data drawn from a wider context of efficiency and performance metrics provides a much richer and fuller picture of international retailing than that revealed by 'topdown' analyses. We have already pointed out the methodological difficulties with the corporate employment data, which are not dissimilar to the problems faced by economists conducting aggregate analysis of retail labour productivity. Such analysis nevertheless highlights the advantageous position in relation to some efficiency and performance variables of UK retailing particularly in relation to space utilisation. Only on one 'pure' productivity metric - sales / profit employee productivity - does UK productivity clearly and consistently lag that of our sample of firms in the US and France.

Our analysis of published corporate data is clearly biased towards larger publicly-quoted companies, although our sample comprises significant proportions of retail trade in the three countries under examination. We have nevertheless been unable to extract comparative data of a similar quality for the 'tail' of smaller retail businesses in either the UK, US or in France. This is a significant weakness in our understanding of retail productivity.

We have demonstrated that there is potentially ample information about how retailers measure the efficiency and performance of their businesses. These are the best measures for all to use, as these are the measures that retailers use directly to drive their businesses. Macro-economic analyses of total factor productivity are of no practical help or interest to retailers, since such analyses transmit no information which indicates where action might be taken. From the interviews conducted with a variety of retailers, the consensus emerged that no single measure of productivity is sufficient to capture the efficiency of input utilisation in retailing, but there is broad agreement over what the list of measures looks like. However, there is no requirement to publish, for example, sales density information, and there is no 'accounting standard' or data standard for a wide range of metrics relevant to productivity.

\section{STRUCTURAL AND ENVIRONMENTAL EXPLANATIONS FOR DIFFERENTIAL PRODUCTIVITY}

Whilst we have demonstrated that there may be difficulties with simple measures both of labour and total factor productivity for international comparative purposes, it is not unreasonable to think that there may well nevertheless be genuine productivity differences between countries. A range of factors will be important in explaining the relative performance of the retail sector in different countries. Some of these may arise from structural variations between markets. These includes the composition of the sector in terms of size and format of businesses, and the positioning choices retailers make, which are themselves inextricably linked to the product/service output mix demanded by consumers.

There may be also be differences as a consequence of dissimilar regulatory environments. Regulatory environments limit propositions in certain ways. For example, shorter trading hours in Germany mean consumers have to accept shorter hour propositions - which are 'efficient' in labour productivity terms, but less efficient in terms of the use of capital or space. Of course increased hours / supply may drive demand too, so that it is clear that the German government is 
interested in the possibility of lengthening hours to stimulate moribund consumer demand. In the UK, regulation limits the development of very large free standing stores. These propositions can be more efficient in terms of economies of scale in labour use or goods deliveries for instance.

\section{Structural explanations}

\section{Differences in country propositions}

An overwhelming majority of UK retailers interviewed for this research rejected any notion of UK retail productivity being significantly worse than other countries. While one might - in the light of the Work Foundation's report on UK business attitudes to productivity generally (Work Foundation, 2003) - consider that this may be a myopic view, the strength of the response suggests that we should look carefully at what underlies it. The main explanation offered for differences between the UK retail sector and that in other countries - particularly the USA, France and Germany - is suggested by our respondents to relate to structural differences in the retailing propositions in those countries:

"There is constant tension between the abstract model of efficiency and what is actually attractive to the customer. This differs by country. There is a differential trade-off between the efficiency and customer appeal." (UK food retailer interview)

One might argue that UK consumers are unable to express a preference for lower cost/ more efficient propositions - because the UK retail market is less competitive than it might be. The strength of competition has been recently examined of course particularly by the McKinsey Global Institute (McKinsey, 1998) and for the grocery sector, the Competition Commission (Competition Commission, 2000). It does seem clear that UK consumers - some of them, some of the time - express preferences for higher service propositions, which include non-tangible outputs (that is to say brand propositions) over those which emphasise price based on simple efficiencies. Industry participants see retail productivity as a consumer-mediated phenomenon, although this risks confusing what is meant by productivity to the economist. Economists might suggest that consumer mediation is an expression of preferences and the price consumers are prepared to pay to satisfy them. Consumers may indeed have preferences which include low prices and also quality service manifested in (for example) wide and relevant choice (including brand or not) in accessible shopping locations. In this case, product market competition and the nature of consumers' trade off between product price and service will determine value added. Productivity is the relationship between this and the cost of the resources needed to create the value added.

"We could, for example, increase labour productivity by withdrawing all our bag packers. But this would be bad for customers, bad for competition and, ultimately, less profitable." (Retailer)

These preferences in terms of trade-off appear to be remarkably resilient. As the Finance Director of one of the UK's largest retailers put it:

'I think the fact that ASD A basn't increased its price differential relative to the other grocers any more than it ever was means that they are not making super-profits, because I really believe they'd be taking the return and investing everything else in price to make themselves even more competitive. And it doesn't seem to be happening as much as it could be - which makes me think that when ASD A came in they thought they'd be able to drive more efficiencies out. And it just hasn't happened." (UK retailer interview) 


\section{Differences in corporate structure}

The largest European retailers, on average, are smaller than their North American counterparts in market capitalisation terms, but larger than their Japanese and Asian peers. The biggest UK retailers in sales turnover are smaller than the top USA firms, and indeed smaller than several continental European competitors (Table 6). Simple as this finding might appear, it signifies substantial potential performance differences in retailing (Dragun, 2003). Most obviously, scale advantage in buying - global purchasing power perhaps - has become more and more significant in retailing (Dawson, 2000). The largest firms have buying power which smaller ones are unable to match, with consequences for price and competitive strength. However, while buyer power might well, and probably does, have a significant impact on retail "price and competitive strength", it can only have a marginal effect on productivity (for example by means of associated scale effects on the costs of handling the greater throughput and storage of goods, or efficiencies in administration). Nevertheless, the largest UK retailers still do not have the scale of the largest elsewhere in, for example, areas like ICT purchase. Explanations lie at last partly in the limited size of the domestic market, combined with the slowness to develop substantial overseas businesses until recently.

A further element of the structure of the UK retail sector to consider is the significance of the small firm, and the small shop. If large firms are at least comparable on various performance measures with those in other countries, as we have suggested in the previous section, then is there a performance issue among smaller firms? The question is not so much whether smaller firms have difficulties and are likely to be less productive, but more whether there is a greater 'tail' of small firms in the UK sector (Kirby and Law, 1981; Dawson, 1983; Smith and Sparks, 2000).

It is surprisingly difficult to make proper comparisons of the structure of the sector in different countries. We have referred to data deficiencies elsewhere. We are unable to provide a rigorous detailed macro-level comparison of various size firms and various sized stores, across Europe or between the UK and the USA, although some general observations are possible. US Census data for 1997 suggest that $26 \%$ retail sales are accounted for by single unit enterprises. UK data for 1994 from the Retail Inquiry show about 23\% of total retail turnover in businesses with a single outlet. While this says almost nothing about efficiency within the two sets of firms, we can see at least that the size of the two sectors is similar, so that it is not necessarily a larger 'tail' of firms per se which explains any UK retail productivity gap. Much further work would be necessary to compare the actual performance of the two small firm sectors.

Process differences - the example of ICT

"Aging technology investment and aging stores are the primary limitations to productivity" (US retailer interview)

Apart from noting the absence of any regulatory constraints as barriers from this US observation, using technology more cleverly, particularly in relation to space, would appear to be one area where there are some noticeably common concerns between the US and UK, but where the McKinsey Global Institute argues (for example) that differential ability to implement technological innovation divides the two retail markets (National Center for Policy Analysis, 2002). The retailers we interviewed agreed:

"The companies I looked at in the UK tended to have the in-house IT departments because it was seen as being a key competitive advantage. In the US, the systems companies tend to develop retail company 
systems more generally which then every retailer took up. It would appear that the internal IT capacity was not seen by US retailers as the key competitive advantage - bence everyone became efficient at the same rate. In the UK, on the contrary, retailers had to replace their systems at different speeds and thus have different systems capabilities and they retain in-house IT systems - which may be extremely costly." (UK non-food retailer interview)

"A clear evaluation of your IT projects is critical. There must be a clearly stated, well defined payback, which exceeds your cost of capital. A disciplined and consistent payback analysis is probably the single most important practice to increase efficiency. I think companies tend to make investments, but then don't actually follow through on whether or not the investment had payback equivalent to what was projected at the time the investment was made." (US retailer interview)

If these observations are generalisable, then retailers may need to use Information and Communications Technology (ICT) more cleverly in the UK. As one UK Finance Director put it, "IT got cheaper, and the physical assets got dearer."

Let us take one example. For retailing, Radio Frequency IDentification (RFID) is a classic example of a potentially 'disruptive technology'. Christenson and Tedlow (2000) define disruptive technologies as innovations that change the economics of an industry, even if they may not be initially profitable innovations. In terms of productivity, there are two points to be made here. The first is that ICT innovations like RFID require significant upfront investment and payback periods, in terms of productivity gains, may be in the order of the 5-15 years identified in studies of ICT investment and productivity; the speed of payback for individual firms being a consequence of their skills in ICT project management and implementation. Secondly, it is clear that an innovation like RFID is not country-specific in its effects (with pioneering retailers in the US, UK and Germany planning similarly serious investments), but the adoption of the technology by a single firm which has a dominant position in any one country market (such as Wal-Mart in the US) might be sufficient to differentially improve the productivity of the sector as a whole in that country.

\section{Environmental explanations}

There is abundant popular perception that environmental conditions, including regulation, differentially affect the operation and efficiency of retailing between countries. There are two questions that should concern us here:

- are there key differences in the efficiency and performance of UK retailing, as compared to that in other countries, which may be attributed to differences in the regulatory environment?

- would de-regulation, or change in regulation of some nature, produce gains in efficiency?

The commonly-held view is that there are differences and that deregulation would produce gains in efficiency:

"In many European industries regulations and structural impediments in product and labour markets limit the opportunities to invest in ICT. Examples of product market restrictions include limits on shop opening hours, and transport regulations that make it difficult for manufacturers and wholesalers to supply customers frequently" (van Ark et al., 2002). 
Many of these costs will have indirect effects upon retail productivity. For example, estimates suggest that the United States loses roughly 2 percent of its gross national product to congestion and that the United Kingdom loses about 5 percent - which will create differential costs for retailers and manufacturers in those countries, (MacKenzie, Dower \& Chen, 1992). Other regulations may have more complex effects. Relaxing trading hours restrictions might reduce labour efficiency, but would increase the efficient use of capital, because of longer trading time from a fixed store. But the overall impact on productivity is uncertain.

\section{Labour costs}

To what extent do regulatory issues in relation to employment make a further contribution to explaining labour productivity gaps between our selected comparator countries?

"The French retail work.force is more inflexible and less efficient than that in the UK - and much more expensive. On the other hand, there is also a greater degree of labour flexibility in the US than in the UK.” (UK retailer operating in France, US and UK)

Paradoxically, it may be as the result of greater regulation rather than less that we can explain in part how France exhibits higher labour productivity than the UK or the US - through higher costs of employment and less flexible policies in areas such as training and promotion. Figure 13 demonstrates that total costs to an employer for a typical manager are almost $30 \%$ higher in France, compared either to the US or the UK because of additional social security contributions. Hourly retail wage costs more generally are lower in the US and the UK, than in France - in the case of US-France by some 8-10\% in PPP terms (Gadrey \& Jany-Catrice, 2000).

The additional per employee costs of employing labour in France means that French retailers will staff stores somewhat differently from their US and UK competitors; fewer part-time and casual workers will be used and more full-timers. This necessarily reduces the flexibility with which French retailers can deploy their human resources in response to perceived customer demand and the operational requirements of the business, despite leading to greater labour productivity. It might nevertheless be useful better to understand the characteristics and consequences of French retailers' use of labour.

Other human resource areas also differentially affect the ability of retailers in different countries to use staff efficiently or control total costs related to labour.

"There are substantial differences in approaches to staff training \& progression, which is much more rigorous and formal in France and Germany than in the UK." (UK retailer interview)

"If I look back over the last five years and look where I added cost to the business, HR would be such an area. To minimise our risks in terms of industrial tribunals, employee grievances, the whole area of ensuring that we treat people well, we added eight people to handle these issues for our business." (medium-sized non-food UK retailer interview)

In the comparatively deregulated environment of the US, retailers we interviewed see fewer barriers to enhancing labour productivity, although some exist:

"Our primary constraints to realizing ever increasing labor productivity are related to costs - specifically, the rapid rise in the cost of health insurance. In the US, this is rising at a factor many times greater that the rate of inflation and there is no sign of this slowing." (US retailer interview). 


\section{Space, Planning and Property}

Retailing performance is critically dependent on 'location, location, location'. Setting aside questions of e-commerce, retailing is an inherently local activity: its essence is local distribution. The property environment therefore is a key influence on performance. The locations, sizes and kinds of shop premises available, the sizes and natures of shopping centres, the nature of ease of accessibility to centres and to shops are all important considerations (Guy, 1994).

There are three broad ways in which the property environment may inhibit improved performance. First is by constraining competition through rigidities in the system: both entry to and exit from the market may be restrained. The second is through actual supply: sub-optimal size, shape, location and condition inhibit performance - particularly logistical performance. A lack of large store premises prevents retailers benefiting from economies of scale. One may certainly draw attention to the fact that much UK (and other European) retailing takes place in historic buildings and town centres: the relatively young age of US shop property must be an efficiency advantage. Thirdly, the cost of property may be high.

The most profound difference between US retailing and UK retailing is in the property environment:

"Retail development in America has tended to be a fairly low-cost, rather risky and disorganised part of the urban economy. Shops and centres frequently fail through competitive pressures.... and public policy makers show little concern over this process. In Britain, a planning system which in any case restricts land for new development has been further used by existing interests (commercial and financial) to limit the volume and location of new retail development. Retail development is thus high-cost, secure and organised, a state of affairs regulated by market forces as much as by public interest.. We conclude therefore that contrasts in urban retail structure between the two countries reflect underlying societal characteristics..." (Guy \& Lord, 1991).

Retail property costs are generally accepted to be higher in the UK than in France and the USA our comparator countries. Published rental comparisons are not as helpful as they might be in assessing this difference, as they tend to focus on capital cities rather than the market as a whole. A careful piece of work by Guy and Lord compared the retail structure of two similar cities in detail (Guy \& Lord, 1993). Their study showed a total amount of retail floorspace in the US city of Charlotte more than twice as great as in Cardiff. Top retail rents in the latter were six times those in the former. More recent work by Deutsche Bank showed comparative land costs for specific grocery retailers. US costs were given as $\$ 500$ per sq metre or below; those for continental European firms were below, often substantially below, $\$ 1,500$. UK retailers all showed costs of over $\$ 2,500$ (Deutsche Bank Research, 1999).

The UK is a small country and land and floorspace are more expensive because less plentiful than in France or the UK. Supply is generally constrained and it should be noted that land values in general are high and retail land prices are probably underpinned by values for alternative uses. Our interviews with retailers for this study showed that they are particularly concerned about the costs, and the rising costs, of property. Property or rental costs are not generally given in corporate accounts and so there is no good data available to show rent as proportion of sales, comparing UK with other countries, or showing change over time in the UK (Burton, 1992). It was strongly suggested by our respondents that property costs have risen over the last decade at a greater real rate than retail sales. Figure 14 shows that property taxes generally are some $20 \%$ higher in the UK than in either France or the US and are increasing. 
The regulatory framework for the UK retail property market is dissimilar from other European countries and from the USA. Concerns about the implications of this framework and about certain practices in the commercial lettings market have been well rehearsed (Burton, 1992). They include anxiety that leases and the workings of the property market are not well understood by smaller tenants. More generally, there are concerns that upward-only rent reviews are imposing unjustified costs, that confidentiality clauses and other practices make the market less than transparent, and that restrictions on ending or re-assigning leases cause problems. Finally, long leases may work to inhibit flexibility. A detailed study of international leases showed that differences in the UK are indeed significant (Crosby \& Murdoch, 1998). Lease lengths are shorter, not just in emerging markets but also in the USA, Australia and other parts of Europe. Long leases, with a commitment of 15 or 25 years, with onerous costs and conditions for breaking the lease, assigning or sub-letting may inhibit flexibility and impose entry and exit barriers on the retail industry, with consequences for cost or efficiency. These concerns have been addressed by various reforms and lease lengths in retailing have fallen consistently over the past ten years (British Property Federation, 2003) but still remain longer than other property sectors and longer than in other countries.

Work undertaken by OECD has suggested that the main restrictions on market entry in the commercial distribution sector in the OECD countries are linked to regulations on large stores (Boylaud \& Nicoletti, 2001). Restrictions, they say, have three consequences: they slow down modernisation and consolidation in the sector; they benefit incumbent firms and make it difficult for a new competitor to enter the market and may speed tendencies to concentration at the national level; finally, they may reduce firms' market power over their suppliers. All European countries restrict to some degree the development of large stores (Davies, 1995) and restrictions have often been increasing (Davies, 2003). There are various motivations and national and local policy reasons for such limits. Broadly they relate to urban and regional planning, to environmental and traffic concerns, to concern for accessibility to services and social equity, and to concern for small shops and centres.

Recent research has attempted to quantify the restrictive effects of such regulation (Boylaud \& Nicoletti op.cit.). It finds (with the caveats that local regulation is not included, and that regulation may be strict on paper and flexible in practice) that the UK is somewhere in the middle of the range across OECD countries. The USA is not included in the OECD analysis. However, we can say that store development regulation there is far less restrictive than in any EU country.

"the prime example of minimal strategic control over retail development is in the United States" (Guy, 1994:93)

However, the issue is not straightforward. It is not the case, for instance, that UK retailers themselves unanimously demand wholesale changes in planning policy (Oxford Retail Group, 2000; House of Commons, 2003). Certainly, there are concerns about the speed of the planning process, the costs of delays, and inconsistencies in decision making. Reform of both planning regulation and the operation of the system is part of current government policy (Office of the Deputy Prime Minister, 2002).

One key issue is about economies of scale. If large scale store development is inhibited, then is the UK industry deprived of economies of scale at the level of store operations? Recent research has demonstrated the difficulty of quantifying the effects of scale at the level of the store (Guy \& Bennison, 2003). It did however show, using evidence provided by retailers themselves, that economies of scale related to store size are important in the UK, and derived from a variety of 
factors. By implication, a further shift to larger stores would produce further economies. The Competition Commission found economies of scale in staff costs in its examination of UK supermarkets: the effects were greatest for smaller stores and extended up to 3,000 sq metres, but were modest above that (Competition Commission, 2000). In retailing generally in the UK, not just food supermarkets, average store size is very much below this - well below 500 sq metres (CB Hillier Parker, 2001). Table 7 shows, for example, that the average size of supermarkets in the UK was some 1,600 sq metres, compared to just over 3,000 sq metres in the US. It is not simply that large new stores can be operated more economically. The proposition changes with larger new stores too: the range, the presentation to the consumer can be more compelling in a larger store, so footfall and sales themselves increase in a non-linear way. There is little doubt that economies of scale at store level are easier to obtain in the USA than in the UK. Differences between the UK and other EU countries are much less significant.

Finally, an important element of regulatory differences between retail markets - especially between those in the US and UK - are those arising from transport and distribution. UK posttax diesel prices are some three times as high as those faced by US retailers, but total costs are of course determined by distances travelled as well as by unit costs. We can obtain a more representative picture by examining the total cost of operating a vehicle of a particular size in different countries (see Figure 15). This demonstrates that total operating costs in Spain are 23\% less, and in France 17\% less than those in the UK. The major contributory factors are: cost of fuel, maintenance and motor vehicle taxation. Not all factors are quantified, however. Such policies as locally-imposed delivery restrictions - especially if applied by a large number of towns in an area - can provide significant obstacles to efficiency of distribution. The Freight Transport Association estimated that growth in goods vehicle traffic could be reduced by more than 50 per cent and the number of lorries on the road cut by 21,000 were local authorities to remove the current night-time delivery restrictions that are in place by 2010 (Freight Transport Association, 2003). Of course, such restrictions have their own environmental justification and are part of other trade-offs.

We do not believe that further analysis will produce obvious recommendations for additional reforms which would improve retail productivity in the UK. The question is not a technical one about what kind of action might have an effect, but rather a policy one, about the kinds of urban and regional environment, the kinds of town and city centres, that the UK wishes to have and, as such, is beyond the remit of our research.

\section{CONCLUSION}

It is a fact that labour productivity in the UK is relatively low. It is also a fact that retailing is one of the main users of labour in the UK. Therefore it follows that retailing may well exhibit low labour productivity and could be expected to contribute relatively heavily to the UK's overall low labour productivity. The word "contribution" might be correct. However, there is nothing necessarily causal implied. That is, there is no reason to believe that the policy implication (if it exists) lies in the retail sector. The policy implication might lie in the wider labour market. Simply because retailing uses a lot of labour so that it looks less productive than other sectors, it by no means follows that retail is making less valuable use of each element of labour than any other business. In addition, problems with retail statistics in particular make it unwise to draw very firm conclusions about differences between labour productivity in UK retailing and retailing in comparator countries.

However, whether or not retailing in the UK is, for whatever reason, more or less productive in any particular respect than in other countries, there are no grounds for complacency. Even the 
most successful leading firms should always be seeking ways to become more efficient within the context of their customer offer and the competitive and regulatory environments within which they trade. Our work has nevertheless moved beyond the simplistic idea that regulation is a brake on retail productivity, to the recognition that a complex mix of urban characteristics, consumer preferences and competitive rivalries, influence the structure and performance of UK retailing, as elsewhere.

Our most important conclusion is about the need to improve data collection on and analysis of the retail industry. Our research raised questions about the aggregate statistics we have, and also showed that different kinds of information would be helpful in improving the dialogue between retailers and government. Retailing is undoubtedly a major sector of the UK economy, yet there is considerable uncertainty about, for example, the significance of the non-labour factor' contributions to the generation of retail output. In particular, more attention might be given to, for example, the relevance of differences in supply of land and associated marked variations in retail occupancy costs between countries, and to the nature and importance of capital investment in the sector.

We conclude also that there is a need for:

- the extension of firm level analyses by National Statistics and at the national level by OECD

- more integration and harmonisation of existing official and unofficial data sources relevant to retailing

- work towards the development of more meaningful disaggregation of the industry exploring the potential for developing metrics which can be shared between retailers and government

- the evaluation of measures used by US retailers for use within the UK, and

- the development of an integrated consumer satisfaction measure to reflect the perceived quality aspects of retail propositions and service levels.

The recommendations we made in our report to government covered these issues, as well as more general recommendations on improving the dialogue between the industry and government. But our central conclusion is that official statistics need improvement if we are to have confidence in policy measures based upon them. Although we focused on the UK, and on comparing performance in the UK with elsewhere, the issues are more general. Official statistics on retailing - and other services - are nowhere as revealing as they are about the manufacturing sectors. Further, good international comparisons between retailing performance in different countries would provide a rich field of research. This requires moves towards the harmonisation of metrics at the business level. The academic research community should also take up the challenge to increase our understanding of the retail sector.. The conceptual problems associated with defining retail output and categorising types of retailing, are of course also worth more scholarly scrutiny, although we note that nearly 50 years of attention by economists has failed satisfactorily to resolve conceptual problems in relation to retail productivity and the productivity of services more generally. 


\section{REFERENCES}

Abraham, A., J. Greenlees and B. Moulton, (1998), 'Working to improve the consumer price index', Journal of Economic Perspectives, 12, 27-36.

Barnes, M., (2002) 'Manufacturing and Services in the UK: How do they compare?' in ONS/DTI Productivity Workshop.

Blanchard, O., (2003), 'Comments on "The case of missing productivity growth; or, why has productivity accelerated in the United States but not the United Kingdom" by Basu et al.' in NBER Macroeconomics Conference.

Bliss, C.J., (1988), 'A theory of retail pricing', Journal of Industrial Economics, 36, 375-392.

Blow, L. and I. Crawford, (2001), 'The cost of living with the RPI: substitution bias in the UK RPI', Economic Journal, 111, F357-382.

Boskin, M. et.al., (1996), Toward a more accurate measure of the cost of living, Final Report to the Senate Finance Committee.

Boylaud, O. and G. Nicoletti, (2001), Regulatory Reform in Retail Distribution. OECD Economic Studies, 32: p. 253-274.

British Property Federation and I.o.P. Developers, (2003), Annual Lease Review.

Brown, S., (1986), 'Retail classification: a theoretical note'. Quarterly Review of Marketing, (Winter): p. 12-16.

Brynjolfsson, E.H., Lorin M. Shinkyu Yang, (2002), 'Intangible Assets: Computers and Organizational Capital'., in Brookings Papers on Economic Activity, Brookings Institution Press. p. 137.

Burton, J., (1992), Retail Rents - Fair and Free Market, Adam Smith Institute: London.

CB Hillier Parker, (2001), British Shopping Centre Development

Christenson, C. M. and Tedlow, R.S. (2000), 'Patterns of Disruption in Retailing'. Harvard Business Review 78 (1) p 42

Competition Commission, (2000), Supermarkets: A report on the supply of groceries from multiple stores in the United Kingdom.

Crosby, N. and S. Murdoch, (1998), Changing Lease Structures in Commercial Property Markets, Royal Institute of Chartered Surveyors: London.

Davies, R.L., (1995), Retail Planning Policies in Western Europe, London: Routledge.

Davies, R.L., (2003), 'Planning Policy for Retailing', in Retail Strategy: The View from the Bridge, J. Reynolds and C. Cuthbertson, Editors, Butterworth-Heinemann: Oxford 
Dawson, J., (2000), 'Retailing at century end: some challenges for management and research'. International Review of Retail, Distribution and Consumer Research. April, p 119-148.

Deutsche Bank Research, (1999), Global Food Retailing part 1, Deutsche Bank: London.

Doms, M., R. Jarmin, and S. Klimek, (2001), 'IT Investment and Firm Performance in US Retail Trade'. in OECD Workshop on Firm Level Statistics, OECD.

Dragun, D., (2003), 'Stuck in the Middle--or in the Muddle?: Europe's leading retailers in the global value landscape'. in European Retail Digest, Templeton College. p. 1.

Economist, (2003) 'The new "new economy" - American productivity - America's extraordinary gains in productivity.' The Economist, (13 September).

Foster, L., J. Haltiwanger, and C.J. Krizan, (2002), The Link Between Aggregate and Micro Productivity Growth: Evidence from Retail Trade.

Freight Transport Association, (2003) Press Release, http://www.fta.co.uk/news/pressreleases/archive/20031106Relaxingdelivery.htm

Gadrey, J. and F. Jany-Catrice, (2000), The Retail Sector: Why so Many Jobs in America and so Few in France?, in Service Industries Journal, Frank Cass \& Company Ltd. p. 21.

Griffith, R., et al., (2003), The UK Productivity Gap and the Importance of the Service Sectors, AIM.

Gullickson, W. and M.J. Harper, (2002), 'Bias in aggregate productivity trends revisited.' Monthly Labor Review, (March): p. 32-40.

Guy, C.M. and J.D. Lord, (1991), 'Comparative retail structure of British and American Cities'. International Review of Retail, Distribution and Consumer Research, 1(4): p. 391-453

Guy, C.M. and J.D. Lord, (1993), 'Transformation and the City Centre', in Retail Change: Contemporary Issues, R.D.F. Bromley and C.J. Thomas, Editors, UCL Press: London.

Guy, C.M., (1994), The Retail Development Process: Location, Property \& Planning, London: Routledge.

Haskel, J. and N. Khawaja, (2003), 'Productivity in UK Retailing: Evidence from Micro Data', Working Paper, CeRiBA: London.

Hausmann, J., (2003), 'Sources of bias and solutions to bias in the consumer price index', Journal of Economic Perspectives, 17, 23-44.

Hill, T., (ed.) (2000). Manufacturing Strategy. Macmillan, London.

House of Commons, (2000), Environment Select Committee, Shopping Centres, HC210-I, TSO.

House of Commons, (2003), Select Committee on Office of the Deputy Prime Minister, Report on Planning, Competitiveness and Productivity. www.publications.gov.uk/pa/cmslect/cmodpm/114/114m01.htm 
MacKenzie, J.J., R.C. Dower, and D.T. Chen, (1992), The Going Rate: What It Really Costs to Drive, World Resources Institute: Washington, D. C.

Mason, G., (2002), 'High Skills Utilisation Under Mass Higher Education: graduate employment in service industries in Britain'. Journal of Education and Work,. 15(4).

McKinsey Global Institute, Driving Productivity and Growth in the UK Economy. October 1998, McKinsey

Nakamura, L.I., (1999), 'The measurement of retail output and the retail revolution', Canadian Journal of Economics, 32, 408-425.

National Center for Policy Analysis, (2002), Productivity and The Wal-Mart Connection, Daily Policy Digest, $28^{\text {th }}$ February, http://www.ncpa.org/iss/eco/2002/pd022802a.html

ODPM, (2002), Sustainable Communities: Delivering through Planning Second Progress Report, http://www.odpm.gov.uk/stellent/groups/odpm planning/documents/page/odpm pla n $026235 . p d f$

O'Mahony, M. and W. de Boer, (2002), Britain's relative productivity performance: updates to 1999, NIESR.

Oxford Retail Group, (2000), Tensions in Retail Planning Policy, Oxford.

Pilat, D., (2002), 'International comparisons of productivity - key findings and measurement issues'. in ONS/DTI Productivity Workshop.

Quiggin, J., (2003), 'Walmart and Productivity', weblog, August 21.

Reported in National Center for Policy Analysis, (2002), Productivity and The Wal-Mart Connection, Daily Policy Digest, $28^{\text {th }}$ February, http://www.ncpa.org/iss/eco/2002/pd022802a.html

Retail Intelligence, (2000), Department stores in Europe, Retail Intelligence: London.

Scarpetta, S., et al., (2000), Economic Growth in the OECD Area: Recent trends at the aggregate and sectoral level, OECD.

Shapiro, M. and D. Wilcock, (1997), 'Alternative strategies for aggregating prices in the CPI', Federal Reserve Bank of St Louis Review, 79, 113-125.

The Work Foundation, (2003), From Productivity to Performance: The Missing Link.

Triplett, J.E., (1999), 'Economic Statistics, the New Economy, and the Productivity Slowdown'. in Business Economics, National Association of Business Economics. p. 13.

Tripplett, J.E., (2001), 'Should the cost of living index provide the conceptual framework for a consumer price index?', Economic Journal, 111, F311-335.

Van Ark, B., R. Inklaar, and R.H. McGuckin, (2002), "Changing Gear". Productivity, ICT and Service Industries: Europe and the United States, The Conference Board: Washington. 
Table 1 Levels of retail labour productivity, US/UK/France

\begin{tabular}{l|lllll}
\hline Source & Date & measure & UK & US & France \\
\hline McKinsey (1) & 1995 & gross margin $/ \mathrm{hr}$ & 100 & 110 & 125 \\
NIESR (2) & 1996 & value added/hr & 100 & 144 & $\mathrm{n} / \mathrm{a}$ \\
\hline NIESR (2) & 1999 & value added/hr & 100 & 163 & 159 \\
\hline
\end{tabular}

Sources: O’Mahony \& de Boer 2002, McKinsey Global Institute 1998.

Notes: (1) for food retailing only; (2) for retail and repairing; 1996 French data unavailable. 
Table 2 Growth rates in retail labour productivity, US/UK/France

\begin{tabular}{|l|l|l|l|}
\hline NIESR $(1)$ & USA & UK & France (2) \\
\hline $1979-99$ & 2.72 & 2.16 & 1.29 \\
\hline $1979-89$ & 2.59 & 3.11 & 1.86 \\
\hline $1989-99$ & 2.85 & 1.21 & 0.73 \\
\hline $1989-95$ & 1.02 & 0.56 & 0.49 \\
\hline $1995-99$ & 5.59 & 2.18 & 1.08 \\
\hline $\begin{array}{l}\text { Conference } \\
\text { Board (3) }\end{array}$ & USA & UK & France \\
\hline $1990-95$ & 2.3 & 2.6 & 1.3 \\
\hline $1995-2000$ & 6.9 & 3.5 & 0.9 \\
\hline
\end{tabular}

Sources: NIESR, Conference Board

Notes: (1) Value added per person: \% growth rate per annum

(2) For distributive trades (retailing not available)

(3) Value added per employee: \% growth rate per annum 
Table 3 TFP growth in the US and the UK in the 1990s

\begin{tabular}{|l|l|l|l|}
\hline & $1990-1995$ & $1995-2000$ & Acceleration \\
\hline US & & & \\
\hline Overall & 0.9 & 2.1 & 1.2 \\
\hline Retail trade & 0.8 & 5.3 & 4.5 \\
\hline UK & & & \\
\hline Overall & 2.6 & 1.3 & -1.3 \\
\hline Retail trade & 0.5 & -1.2 & -1.7 \\
\hline
\end{tabular}

Source: Basu et al, 2002 
Table 4 Ranking retail efficiency: space and employment measures, top 20 largest retail firms*

\begin{tabular}{|c|c|c|c|c|}
\hline Rank & $\begin{array}{l}\text { Profit density, net profit } \$ \\
\text { per sq foot of net selling } \\
\text { space }\end{array}$ & $\begin{array}{l}\text { Sales density, \$ per sq } \\
\text { foot of net selling } \\
\text { space }\end{array}$ & $\begin{array}{l}\text { Employee productivity } \\
\text { - Sales, \$ '000 per } \\
\text { employee }\end{array}$ & $\begin{array}{l}\text { Employee productivity - } \\
\text { Net Profits, \$ '000 per } \\
\text { employee }\end{array}$ \\
\hline 1 & Next & Carphone Warehouse & Carphone Warehouse & Selfridges \\
\hline 2 & Hot Topic & Morrison & Dixons & Carpetright \\
\hline 3 & Abercrombie \& Fitch & Next & Circuit City Stores & Bed Bath \& Beyond \\
\hline 4 & Morrisons & Safeway & Selfridges & Home Depot \\
\hline 5 & Marks \& Spencer & Sainsbury & Tractor Supply & Talbots \\
\hline 6 & Selfridges & Zale & CVS & Lowe's \\
\hline 7 & Williams Sonoma & CVS & Best Buy & Marks \& Spencer \\
\hline 8 & New Look & Tesco & Home Depot & 99 Cents Only Stores \\
\hline 9 & Carphone Warehouse & Williams Sonoma & Rite Aid & Abercrombie \& Fitch \\
\hline 10 & Talbots & WHSmith & Casino & Autozone \\
\hline 11 & Tesco & Whole Foods Market & Walgreen & Kohl's \\
\hline 12 & CVS & Marks \& Spencer & Lowe's & Ross Stores \\
\hline 13 & Sainsbury & Hot Topic & HMV Group & Dixons \\
\hline 14 & Home Depot & Best Buy & Carrefour & Matalan \\
\hline 15 & Autozone & Selfridges & Marks \& Spencer & Next \\
\hline 16 & Limited Brands & Circuit City Stores & MFI & MFI \\
\hline 17 & Whole Foods Market & HMV Group & Kroger & New Look \\
\hline 18 & Matalan & Dixons & Safeway & Tractor Supply \\
\hline 19 & Publix Super Markets & Carrefour & Wal Mart Stores & Walgreen \\
\hline 20 & Pacific Sunwear & Publix Super Markets & Carpetright & Hot Topic \\
\hline
\end{tabular}

Source: OXIRM analysis

That is, publicly quoted, predominately retail firms with market capitalisation of greater than $\$ 1$ bn. The highlighted firms are UK-registered and most of their stores are located in the UK. 
Table 5 Ranking retail efficiency: capital and financial measures, the top 20 largest retail firms*

\begin{tabular}{cll} 
Rank & $\begin{array}{l}\text { Rank by ROCE 2003 } \\
\text { (EBIT/Average Capital Employed) }\end{array}$ & $\begin{array}{l}\text { Rank by Asset Turnover } 2003 \\
\text { (Sales/Average Assets) }\end{array}$ \\
\hline 1 & Carpetright & Winn-Dixie Stores \\
2 & Next & HMV Group \\
3 & New Look & Freds \\
4 & Matalan & Publix Supermarkets \\
5 & Tuesday Morning & TJX \\
6 & Ross Stores & Whole Foods Market \\
7 & TJX & Somerfield \\
8 & Bed Bath \& Beyond & Tractor Supply \\
9 & Radioshack & Walgreen \\
10 & Pier 1 Imports & New Look \\
11 & Publix Supermarkets & Tuesday Morning \\
12 & Dollar General & Ross Stores \\
13 & Home Depot & Best Buy \\
14 & Tractor Supply & Matalan \\
15 & 99 cents only Stores & Wal Mart Stores \\
16 & Best Buy & CVS \\
17 & Talbots & Kroger \\
18 & Williams Sonoma & Family Dollar \\
19 & Pacific Sunwear & Petsmart \\
20 & American Eagle Outfitters & WHSmith \\
& & That is, publicly quoted, predominately retail firms with market capitalisation of greater than \\
& The highlighted firms are UK-registered and most of their stores are located in the UK. \\
& &
\end{tabular}


Table 6 Largest retailers 2002

Country of origin

USA

France

Netherlands

USA

Germany

USA

UK

USA

USA

Germany

Germany

USA

USA

France

USA

USA

Japan

Germany

France

UK

Source: M+M Planet Retail
Net sales 2002 (m US\$)

$\begin{array}{ll}\text { Wal-Mart } & 244,524 \\ \text { Carrefour } & 64,774 \\ \text { Ahold } & 59,267 \\ \text { Kroger } & 51,267 \\ \text { Metro Group } & 48,561 \\ \text { Target } & 43,917 \\ \text { Tesco } & 39,521 \\ \text { Costco } & 37,993 \\ \text { Albertsons } & 35,626 \\ \text { Rewe } & 35,276 \\ \text { Aldi } & 33,713 \\ \text { JCPenney } & 32,347 \\ \text { Safeway (USA) } & \\ \text { ITM } & 32,100 \\ \text { Kmart } & 31,572 \\ \text { Walgreens } & 30,762 \\ \text { Ito-Yokado } & 28,681 \\ \text { Edeka } & 27,238 \\ \text { Auchan } & 27,082 \\ \text { Sainsbury } & 25,976 \\ & 25,964 \\ \end{array}$

Sainsbury $\quad 25,964$
3,917

521

35,276

.

31,572

0,762

.

7,082

5,976 
Table 7 Comparisons of food retailing density in the UK, Continental Europe and the US, 1999

\begin{tabular}{l|rrrr}
\hline Item & Spain & France & UK & US \\
\hline Hypermarkets & & & & \\
Number of stores & 267 & 496 & 71 & 650 \\
Square metres ('000) & 2,138 & 4,270 & 391 & 10,000 \\
Average store size (sq m '000) & 8.01 & 8.61 & 5.51 & 15.38 \\
Sq M/1,000 population & 53 & 71 & 7 & 40 \\
Supermarkets & & & & \\
Number of stores & 5,670 & 8,820 & 4,720 & 22,000 \\
Square metres ('000) & 4,540 & 10,350 & 7,600 & 85,000 \\
Average store size (sq m '000) & 0.80 & 1.17 & 1.61 & 3.86 \\
Sq M/1,000 population & 113 & 173 & 127 & 340 \\
\hline
\end{tabular}

Source: Global Food Retailing Part 1, Deutsche Bank Research, 1999 
Figure 1 Some dimensions of retail format

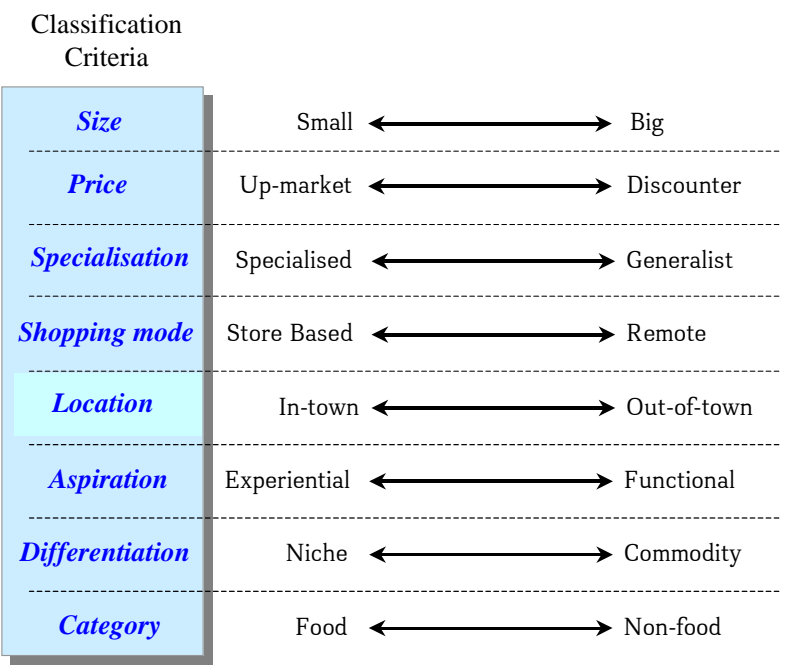

Source: Templeton College research 
Figure 2 Store choice criteria, grocery shopping

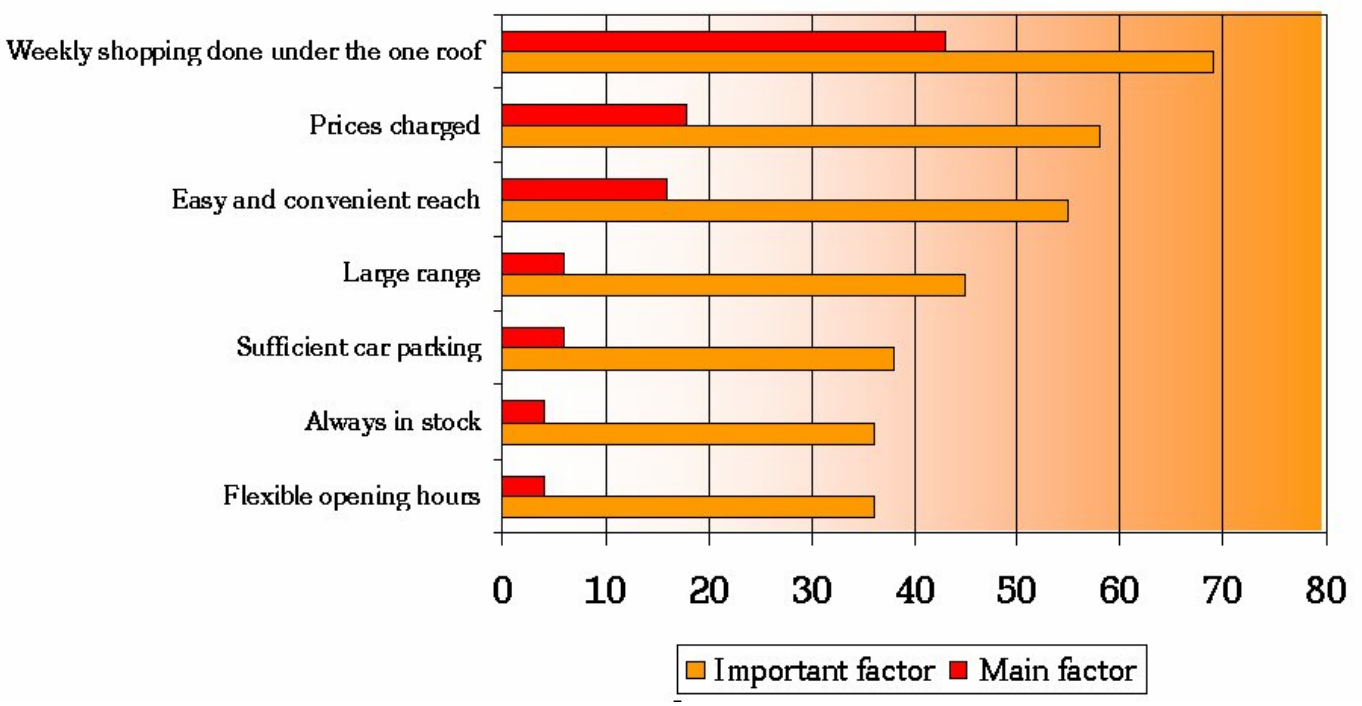

Source: Competition Commission, 2000. 
Figure 3 Wholesale, retail and hire employment mix, EU, 2002

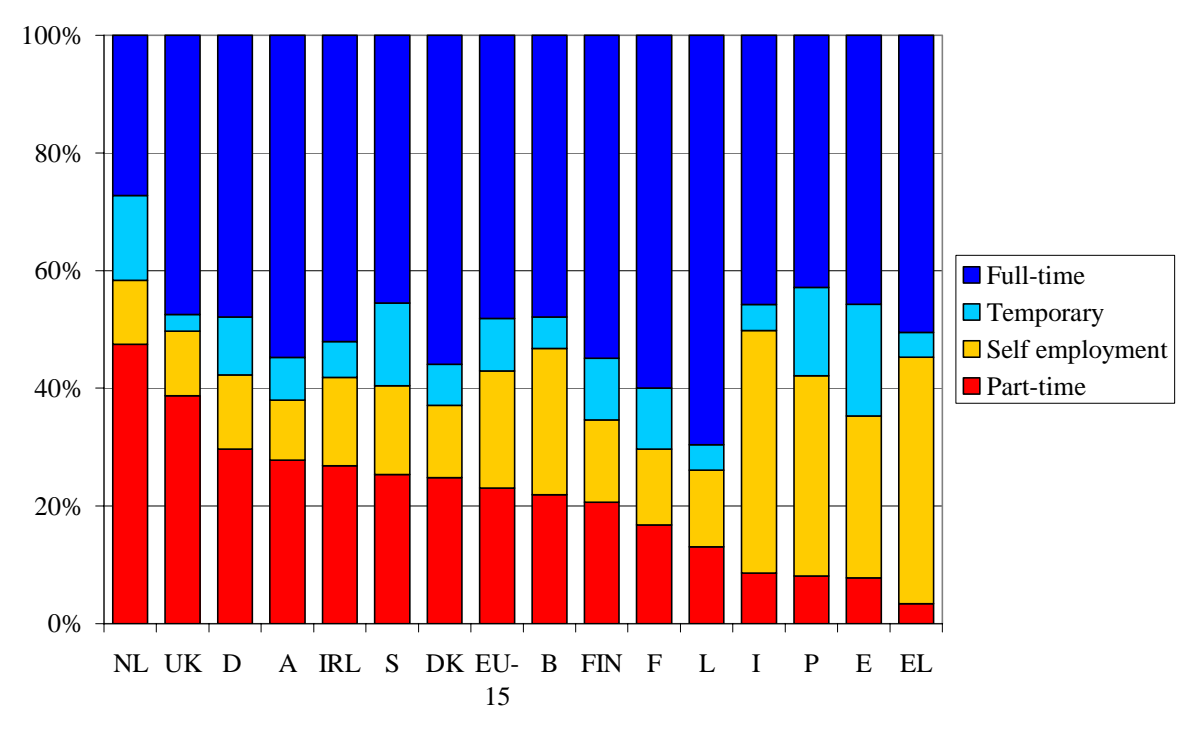

Source: European Labour Force Survey, 2002 
Figure 4 Retail labour productivity growth (Value Added/person engaged) 1990-2000

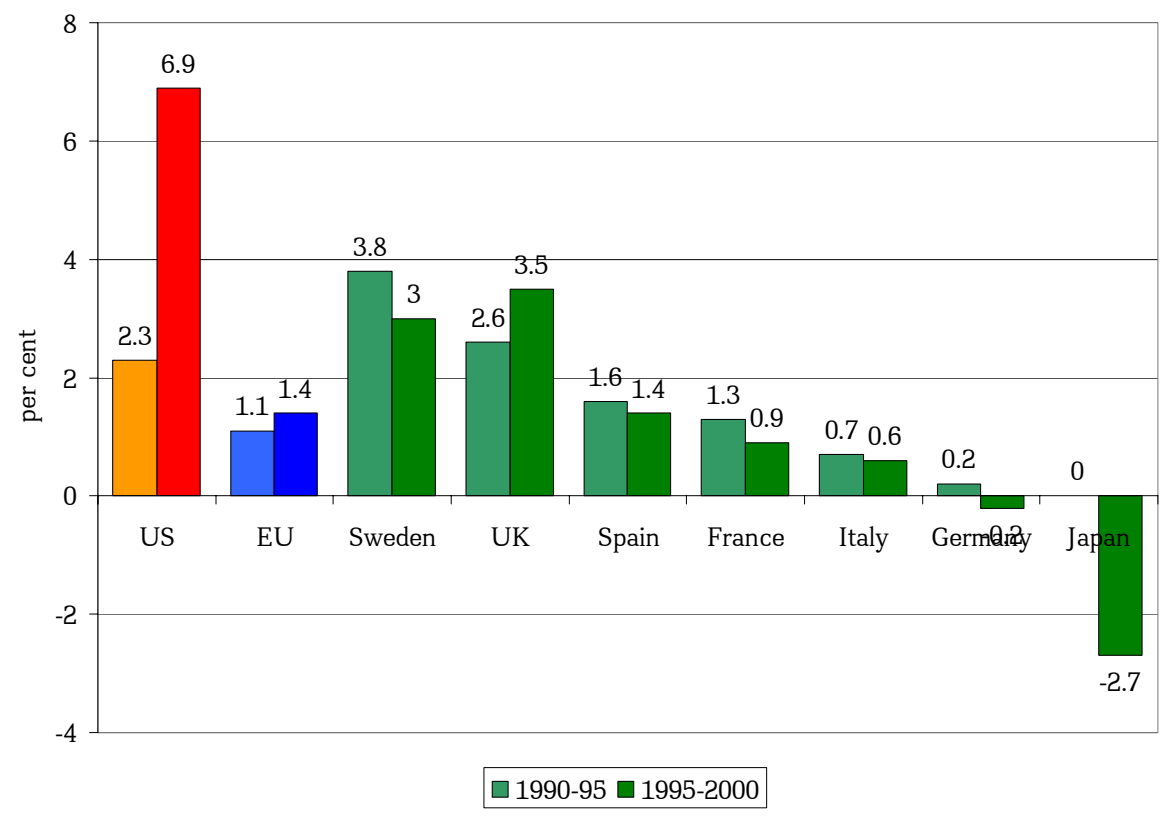

Source: Van Ark et al, 2002 
Figure 5 Components of food retail labour productivity gaps, 1995
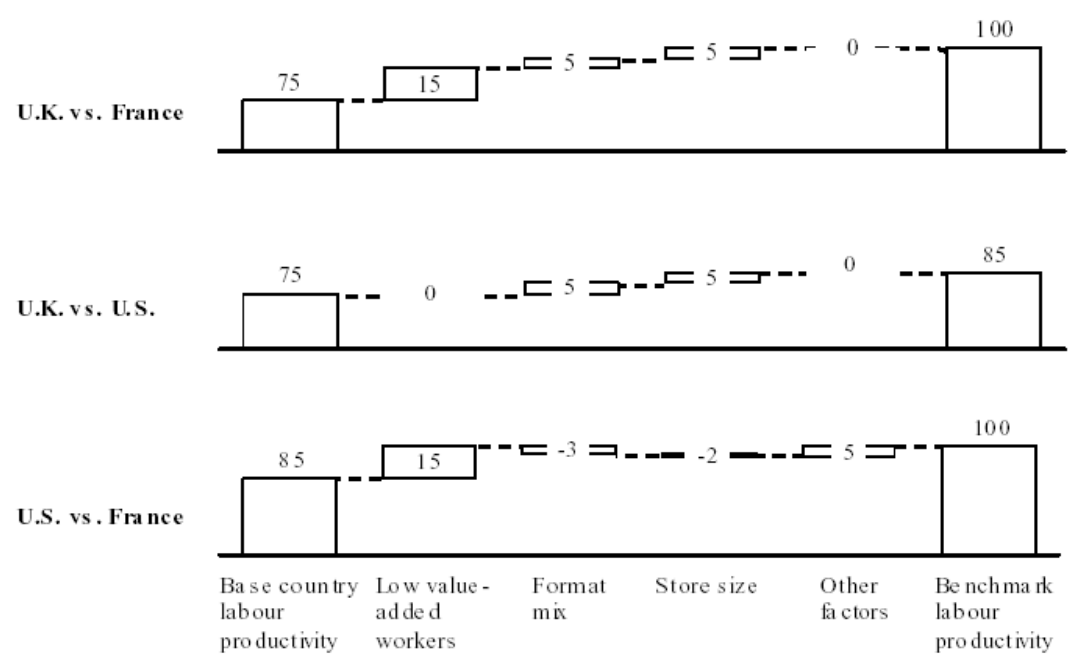

Source: McKinsey, 1998

Note: $\quad$ Indexed to France $=100$. 
Figure 6 GVA productivity by size of business for all retailing, 1998-2001

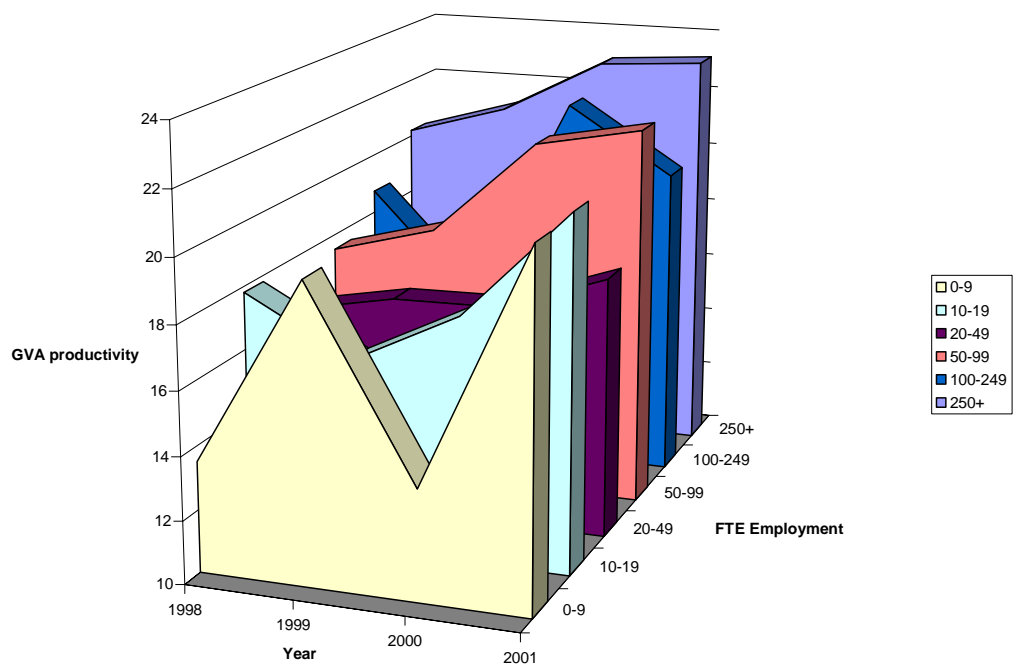

Source: Haskel \& Khawaja, 2003 
Figure $7 \quad$ Employee productivity, Sales per average employee year end in \$US OECD PPP, ‘ 000

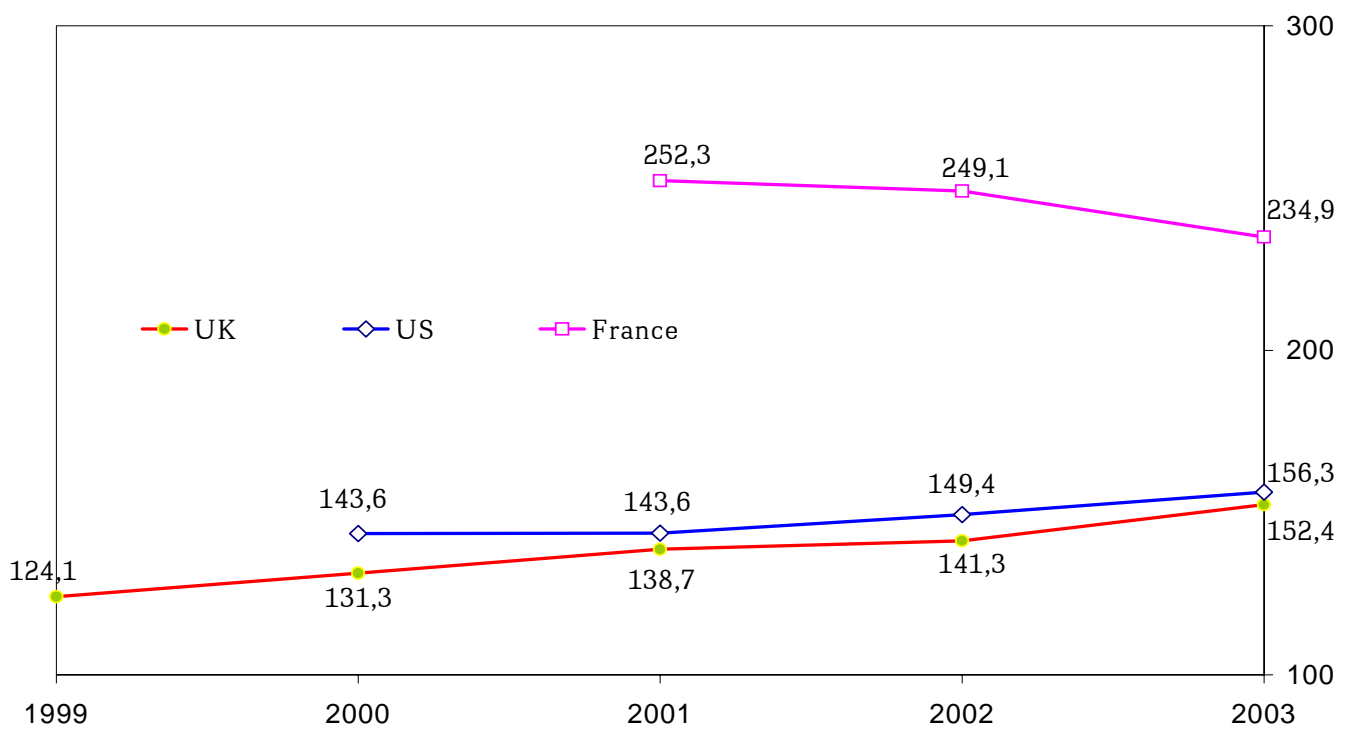

Sources: Company Annual Reports, Datastream, www.planetretail.net, 'The UK Retail Champions' 
Figure 8 Employee productivity, Net profit per average employee year end in \$US OECD PPP, '000

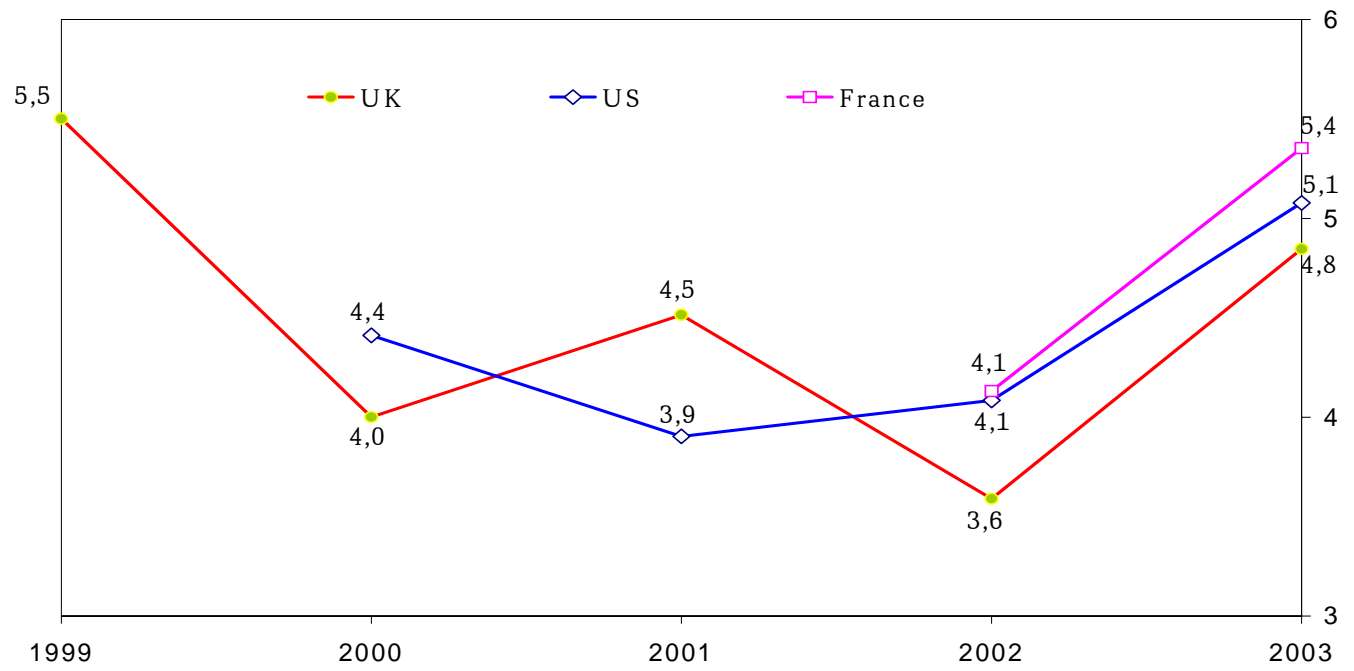

Sources: Company Annual Reports, Datastream, www.planetretail.net, 'The UK Retail Champions' 
Figure 9 Sales density, Sales per sq foot of net selling space in \$US OECD PPP

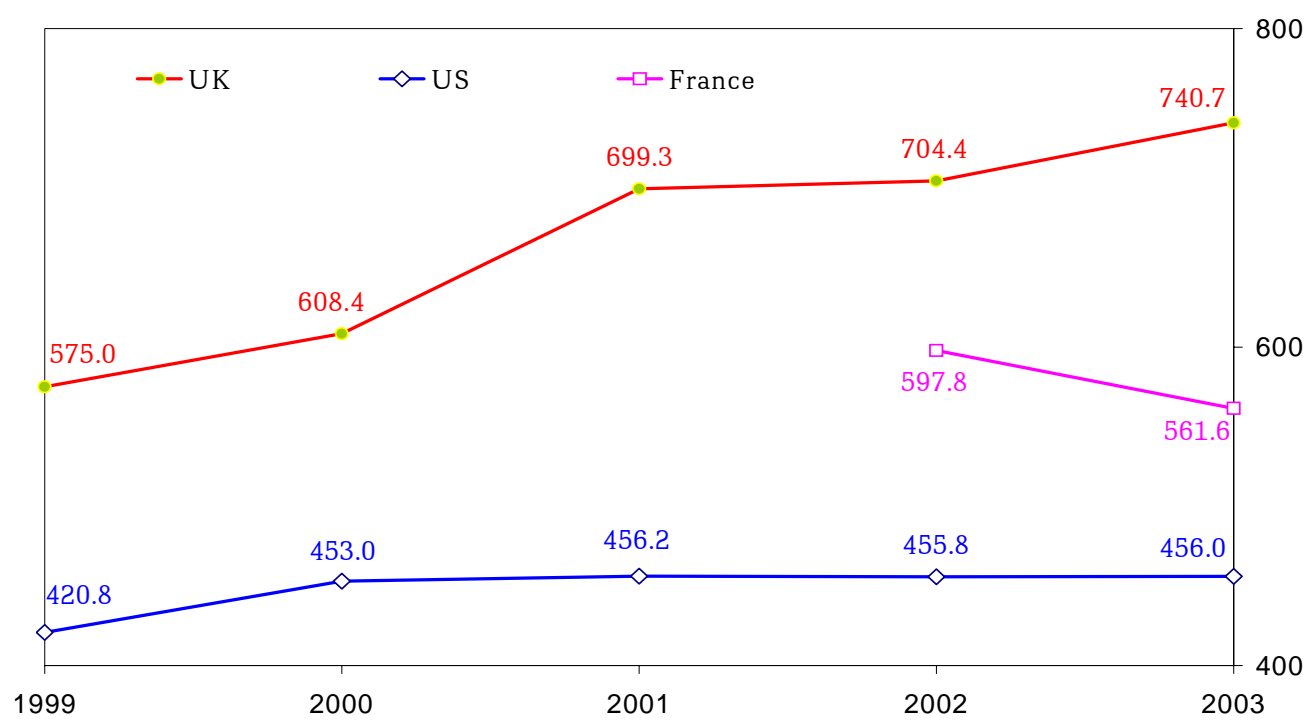

Sources: Company Annual Reports, Datastream, www.planetretail.net, 'The UK Retail Champions' 
Figure 10 Profit density, EBITDA per sq foot of net selling space in \$US OECD PPP

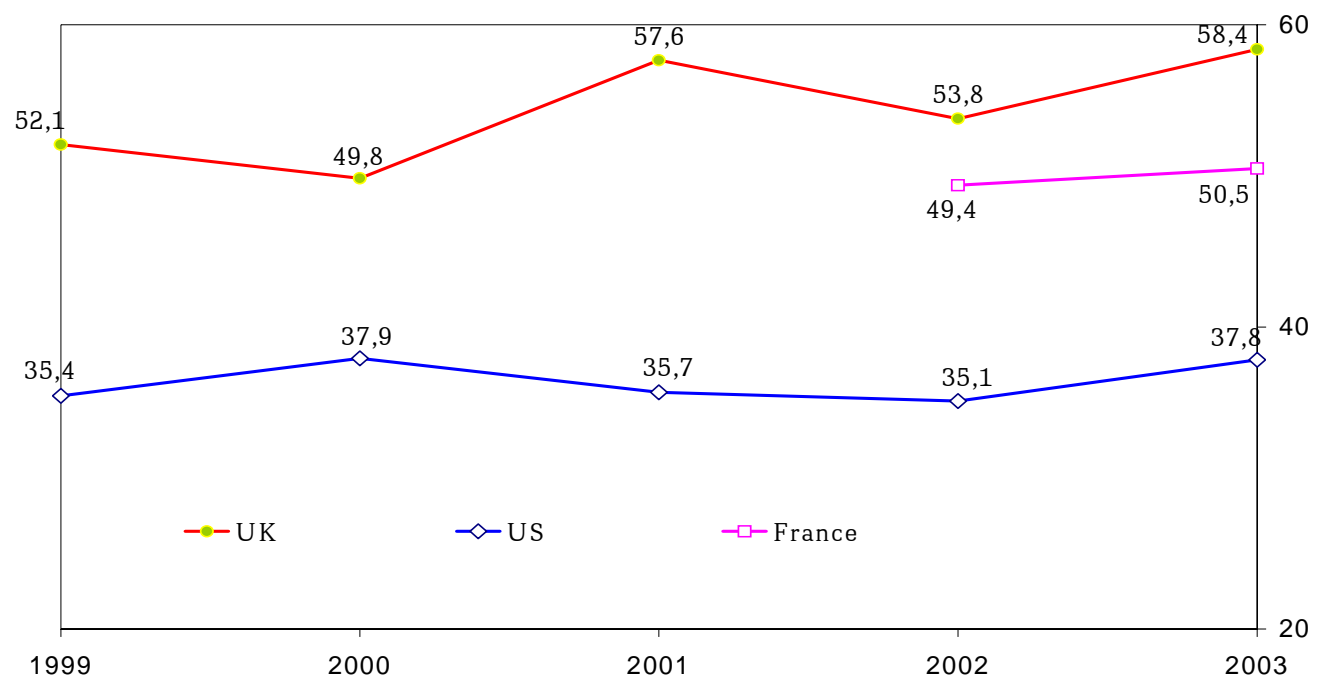

Sources: Company Annual Reports, Datastream, www.planetretail.net, 'The UK Retail Champions' 
Figure 11 Return on capital employed (ROCE)

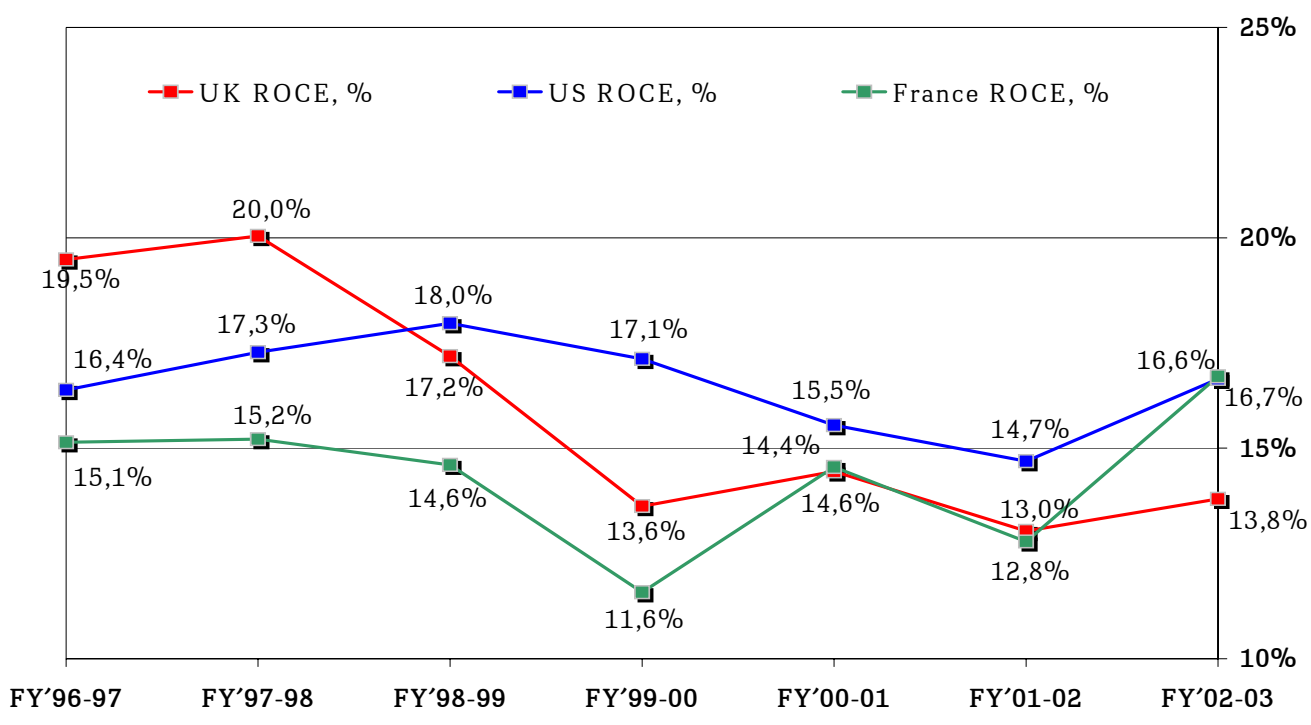

Sources: Company Annual Reports, Datastream, www.planetretail.net, The UK Retail Champions' 
Figure 12 Operating profit margin

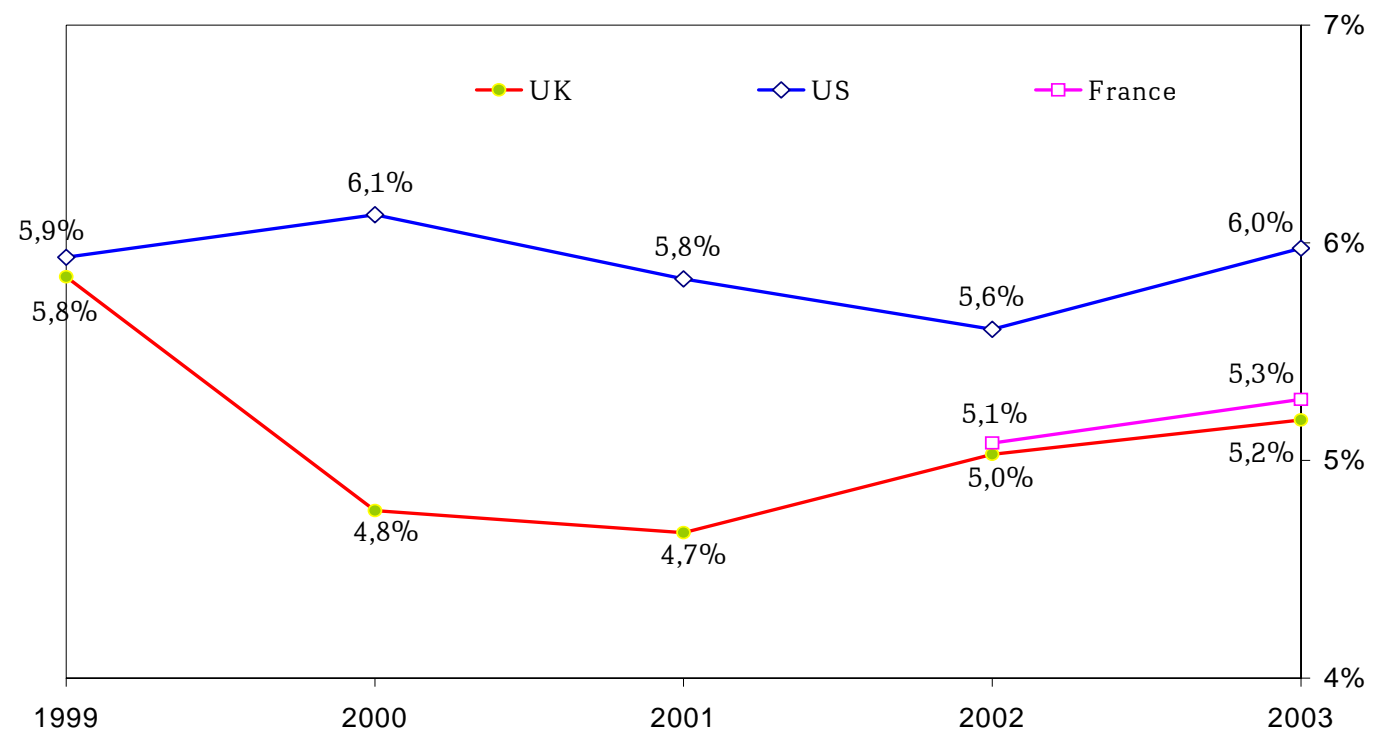

Sources: Company Annual Reports, Datastream, www.planetretail.net, 'The UK Retail Champions' 
Figure 13 Total cost of an executive being paid $€ 50,000$ to employer comparison for France, UK and USA

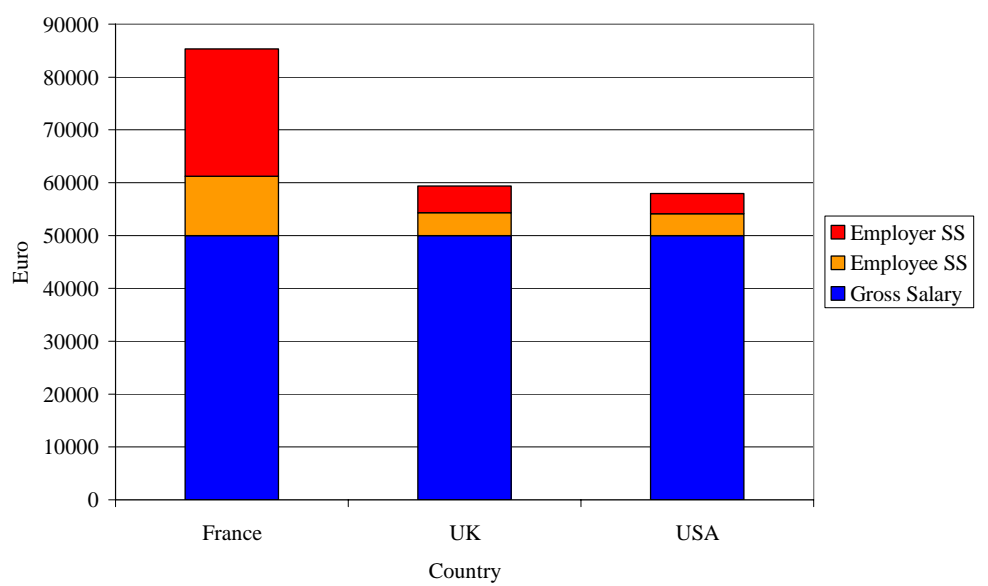

Source: Forbes Global Tax Misery Index, 2003

Note: $\quad$ SS - social security costs 
Figure 14

Taxes on Property as a \% of GDP

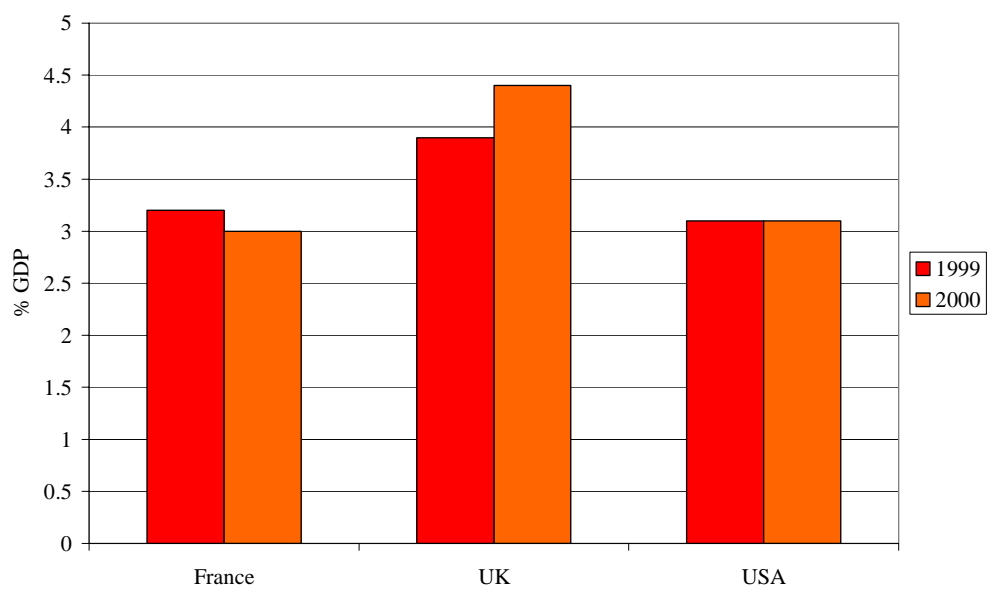

Source: OECD, 2002 
Figure 15 Vehicle operating costs for a 40ton gvw articulated vehicle as at 1 October 2003

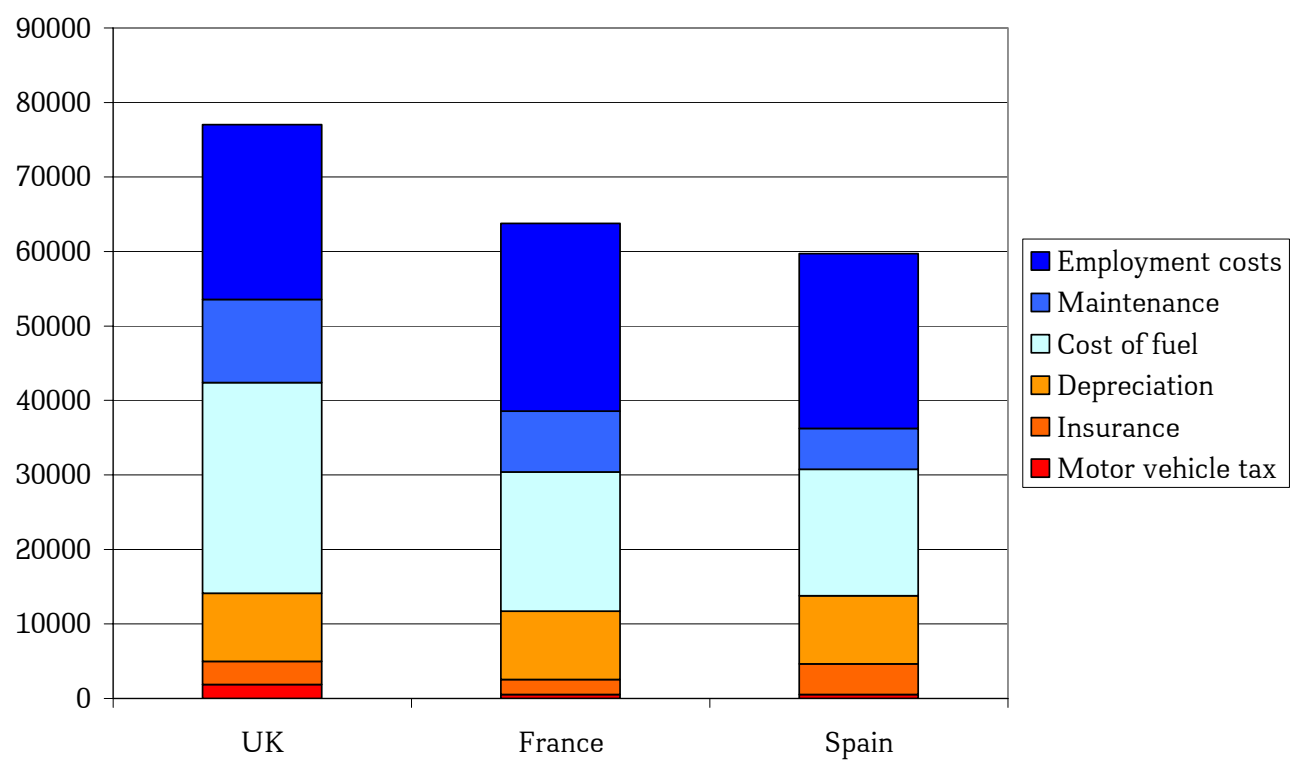

Source: Freight Transport Association, 2003 